\title{
Fryzjer czy fryzjerka? Rodzaj gramatyczny nazwy zawodu jako nośnik statusu społecznego
}

\section{Gender of a profession name as a social status bearer}

\author{
Victoria Kamasa \\ Instytut Językoznawstwa, Uniwersytet im. Adama Mickiewicza \\ ul. Międzychodzka 5, 60-371 Poznań \\ vkamasalwp.pl
}

\begin{abstract}
This article is a report of the results of qualitative research related to the influence of gender of a profession name on the social status of women who use this name. The subject is analyzed in two ways - firstly quantitatively to show the connections between social status related to gender of professions names and different variables, and then qualitatively - to show the character descriptions associated with women, who use profession names in different gender and types of attitudes observed between the respondents.
\end{abstract}

\section{Wstęp}

Celem badań, których wyniki zaprezentowano poniżej, było stwierdzenie wpływu, jaki ma rodzaj gramatyczny nazwy zawodu na status społeczny kobiety, która się tą nazwą posługuje. Wśród poruszanych zagadnień badawczych znalazła się między innymi zależność między przypisywanym statusem a poziomem sfeminizowania bądź zmaskulinizowania zawodu, a także wybranymi cechami społeczno-demograficznymi osób badanych.

Przeprowadzone badania miały charakter pogłębionego wywiadu jakościowego. Respondentom prezentowane były wizytówki z imieniem i nazwiskiem oraz nazwą zawodu. Wizytówki prezentowane były $\mathrm{w}$ parach, w których na jednej $\mathrm{z}$ wizytówek była nazwa zawodu w rodzaju męskim, zaś na drugiej ta sama nazwa w rodzaju żeńskim.

$\mathrm{W}$ pierwszej fazie badania respondenci proszeni byli o opisanie swobodnych skojarzeń dotyczących osoby, do której prezentowana wizytówka należy. Proszono ich również o skoncentrowanie się na cechach charakteru, zdolnościach i umiejętnościach każdej z osób. Druga faza badania polegała na opisywaniu przez osoby badane ich wyobrażeń na temat interakcji pomiędzy osobami (których dane znajdują się na wizytówkach) w sytuacji, w której wspólnie rozwiązują one zadanie zaprezentowane wcześniej respondentom.

Do operacjonalizacji pojęcia statusu społecznego użyto teorii stanów oczekiwań opracowanej przez Josepha Bergera i jego współpracowników, zaś w metodologii badań wzorowano się na 
badaniach prowadzonych przez wspomnianych autorów ${ }^{1}$. Zgodnie $\mathrm{z}$ założeniami tej teorii za wskaźniki wyższego statusu przyjęto przewagę któregoś $\mathrm{z}$ aktorów społecznych $\mathrm{w}$ jednym z czterech wymiarów tzw. obserwowalnego porządku władzy i prestiżu, na który to porządek składają się:

1. Możliwości uczestnictwa $\mathrm{w}$ dyskusji o zadaniu lub problemie, nad którym pracuje grupa (action opportunities) - możliwości działania stwarzane jednemu z aktorów społecznych przez innego aktora; zaliczyć tu można między innymi: pytania, pytające spojrzenia, oferowanie możliwości wniesienia wkładu w rozwiązanie zadania grupowego.

2. Faktyczne próby przedstawienia gotowego rozwiązania problemu (performance outputs) próby wniesienia wkładu w ukończenie zadania takie jak: dostarczanie informacji, sugestii, opinii.

3. Oceny prezentowanych pomysłów (reward actions) - komunikowane oceny osób lub ich działań takie jak: otwarta zgoda z którąś z tez, pochwała, dyskusja nad czyimś pomysłem.

4. Przyjęcie lub odrzucenie wpływu - zmiana oceny lub opinii pod wpływem niezgody drugiego z aktorów ${ }^{2}$ (por. Berger 1977: 38).

Dobór próby odbywał się $\mathrm{w}$ dwóch etapach. W pierwszym miał on charakter doboru kwotowego, który Earl Babbie definiuje jako stworzenie pewnej tabeli lub macierzy opisującej cechy badanych osób ${ }^{3}$ istotne ze względu na cele badania (Babbie 2003). W drugim etapie do każdego z pól stworzonej już tabeli został dobrany jeden respondent. Dobór ten można nazwać za Nachmiasem próbą okolicznościową którą definiuje on następująco: „[jest] to próba, którą tworzą osoby łatwo dostępne. Profesorowie college'u mogą wybrać studentów ze swoich grup; badacz może wybrać pierwsze 200 osób, które spotka na ulicy i które wyrażą zgodę na przeprowadzenie wywiadu" (Nachmias 2001). W przypadku obecnych badań empirycznych wybrane zostały pierwsze osoby odpowiadające cechom wybranej kategorii, które wyraziły zgodę na udział $\mathrm{w}$ badaniach. Dobrana w ten sposób próba nie ma charakteru reprezentatywnego w sensie statystycznym, jednak, jak zwraca uwagę Kvale: „Pod względem ilościowym każdy z przypadków zawierał ogromną ilość obserwacji pojedynczej osoby. Pod względem jakościowym, koncentracja na pojedynczym przypadku daje możliwość szczegółowego zbadania (...) konkretnego zachowania" (Kvale 2004). Próbę badawczą stanowiło 12 kobiet różniących się wiekiem i stopniem sfeminizowania wykonywanego przez nie zawodu.

Prezentowane poniżej wyniki opierają się na danych pochodzących z wywiadów osobistych z poszczególnymi respondentkami, które były nagrywane przy pomocy dyktafonu, a następnie na podstawie nagrania tworzona była transkrypcja, która podlegała analizie. Badania, z wyjątkiem jednego wywiadu mającego charakter badania pilotażowego, przeprowadzone zostały $\mathrm{w}$ kwietniu 2006 roku. Wywiady prowadzone były w miejscu wybranym przez poszczególne respondentki.

Zebrany materiał został poddany analizie zarówno jakościowej jak i ilościowej. Analizie jakościowej poddane zostały zarówno swobodne opisy wizytówek, jak i, choć w mniejszym zakresie, opisy dotyczące wykonania zadań przez pary osób wykonujących ten sam zawód, a posługujących się różnymi formami jego nazwy. Natomiast analizie ilościowej poddane zostały wyłącznie dane dotyczące czterech aspektów obserwowalnego porządku władzy i prestiżu.

Dla celów analizy ilościowej ze swobodnego opisu zachowań obu osób (których dane zostały zaprezentowane na wizytówkach) przy rozwiązywaniu zadania, wyabstrahowane zostały informacje dotyczące przewagi którejś z nich, w każdym z czterech wymiarów przyjętej w tej pracy definicji statusu. $Z$ uzyskanych $w$ ten sposób danych obliczone zostały następujące wskaźniki:

$>$ statusu wyższego, który pokazuje procentowy udział wskazań wyższego statusu którejś $\mathrm{z}$ form nazwy zawodu we wszystkich wskazaniach.

\footnotetext{
${ }^{1}$ Szczegółowy opis tej metodologii opisywanych tu badań znaleźć można w artykule autorki Przykład metodologii badań nad językiem jako nośnikiem statusu, Investigationes Linguisticae, vol. XIII, 2006.

${ }^{2}$ Tłumaczenie pojęć za: Tuner, J. H. 2004. Struktura teorii socjologicznej. Warszawa: Wydawnictwo Naukowe PWN.

${ }^{3} \mathrm{Za}$ istotne cechy w przypadku tych badań uznane zostały: płeć (badaniu poddane zostały jedynie kobiety), a także wiek i poziom sfeminizowania wykonywanego zawodu (jako cechy różnicujące poszczególnych respondentów). Tłumaczenie pochodzi od autorki.
} 


$$
\mathrm{W}=\frac{\begin{array}{c}
\text { liczba wskazań na jednoznaczną przewagę osoby } \\
\text { posługującej się daną nazwą zawodu }
\end{array}}{\text { liczba wszystkich udzielonych odpowiedzi }} \times 100 \%
$$

statusu równego: uzyskany przy pomocy tego wskaźnika wynik oznacza procentowy udział wskazań na równy status obu nazw zawodów we wszystkich wskazaniach.

$$
\mathrm{W}=\frac{\begin{array}{c}
\text { liczba wskazań na równy status osób } \\
\text { posługujących się obiema formami nazwy zawodu }
\end{array}}{\text { liczba wszystkich udzielonych odpowiedzi }} \times 100 \%
$$

W analizie jakościowej wykorzystano metodę typologiczną, a także metodę strukturalizacji sensu poprzez narrację oraz metodę interpretacji sensu. Pierwsza z metod pozwoliła na stworzenie typologii postaw osób badanych, druga zaś posłużyła do stworzenia charakterystyki osób posługujących się poszczególnymi, badanymi nazwami zawodów. Metoda interpretacji sensów, „która wychodzi poza porządek jawnych sensów tekstu do głębszych interpretacji” (Kvale 2004) została użyta do podsumowania charakterystyki każdego zawodu, a także pokazania różnic $\mathrm{w}$ postrzeganiu kobiet posługujących się nazwą zawodu w rodzaju żeńskim lub rodzaju męskim. Stała się zatem środkiem, przy pomocy którego podjęta została próba wyciagnięcia wniosków z uzyskanych w badaniach danych.

\section{Analiza ilościowa}

\subsection{Dane ogólne}

Alicja Nagórko w swoich rozważaniach na temat słowotwórstwa w języku polskim pisała, że męskie nazwy zawodów są lepiej nacechowane pragmatycznie, a także bardziej prestiżowe (Nagórko, 1998). Uzyskane dane z jednej strony potwierdzają tę tezę, z drugiej zaś, przy użyciu tak ostrego i jednoznacznego sformułowania przez wspomnianą autorkę, mogą dziwić niewielką różnica, jaka występuje między nazwami w rodzaju żeńskim a nazwami w rodzaju męskim ${ }^{4}$. Dane ogólne dotyczące wyższego statusu ${ }^{5}$ którejś z form nazwy badanych zawodów obrazuje poniższy wykres:

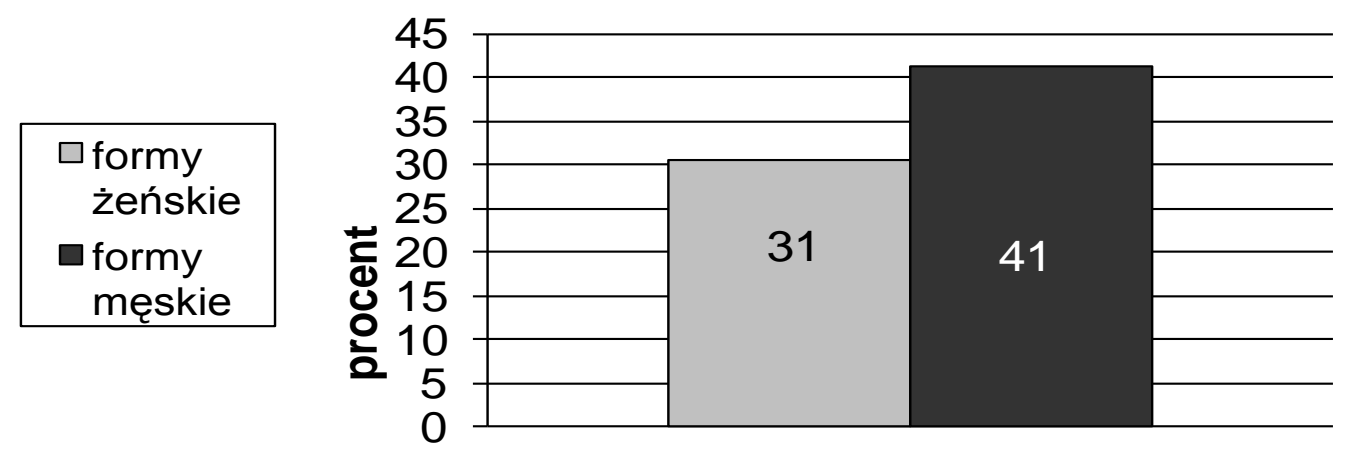

\section{Rys. 1 Status nazw zawodów}

Jak już wspomniano, zebrane dane nie dają podstawy do formułowania żadnych uogólnien, jednak uzyskany dzięki nim obraz badanego fenomenu pozwala wskazać na pewne istotne zjawiska. Może on również stanowić podstawę do dalszych badań o charakterze ilościowym, które będą miały na celu zweryfikowanie postawionych tu hipotez.

\footnotetext{
${ }^{4}$ Sformułowania: ,żeńskie i męskie nazwy zawodów” i „nazwy zawodów w rodzaju żeńskim i męskim” będą w tej pracy używane zamiennie.

${ }^{5}$ Pojęcia: „wymiar statusu” i ,wymiar obserwowalnego porządku władzy i prestiżu” będą tutaj używane zamiennie.
} 
Wyniki wskazują na słuszność twierdzenia Alicji Nagórko - badane nazwy męskie rzeczywiście były częściej niż żeńskie uznawane za bardziej prestiżowe. Jednak ważne wydaje się wskazanie na fakt, że aż w jednej trzeciej przypadków to kobietom, posługującym się żeńskimi formami nazw, przypisano wyższy status niż tym, które używały form męskich. Innymi słowy w ok. $30 \%$ badanych sytuacji to nazwy męskie były mniej prestiżowe i, by posłużyć się słowami wspomnianej autorki, gorzej „nacechowane pragmatycznie” (Nagórko, 1998). Wobec potocznie panującego przekonania ${ }^{6}$, że nazwy męskie cieszą się zawsze większym szacunkiem i prestiżem, jest to wynik dość znaczący, a także zachęcający do dalszych badań w tym kierunku.

Po uwzględnieniu wskazań na równy status obu nazw, różnica pomiędzy statusem nazw żeńskich i nazw męskich uległa zmniejszeniu o połowę. Zarówno w przypadku form męskich jak i żeńskich stwierdzić można, że tylko w jednej trzeciej przypadków status danej nazwy jest niższy niż status nazwy w drugim $\mathrm{z}$ rozważanych rodzajów gramatycznych, a zatem w zdecydowanej większości przypadków status ten jest przynajmniej równy statusowi drugiej z nazw. Dzieje się tak w około dwóch trzecich przypadków - zarówno jeśli chodzi o nazwy żeńskie, jak i o nazwy męskie.

\subsection{Status a poziom sfeminizowania lub zmaskulinizowania zawodu}

Jednym z pytań, które stawiano w prezentowanych tu badaniach, było pytanie o zależność między poziomem sfeminizowania bądź zmaskulinizowania danego zawodu a statusem żeńskiej i męskiej formy jego nazwy. Zakładano, że największe różnice w statusie wystapią w przypadku zawodów zmaskulinizowanych, zaś najmniejsze, być może nawet $\mathrm{z}$ tendencją do faworyzowania nazw żeńskich, w przypadku zawodów sfeminizowanych. Jednak przeprowadzone badania jedynie częściowo potwierdziły tę hipotezę.

We wszystkich trzech kategoriach zawodów badane osoby częściej wskazywały na wyższy status osoby posługującej się męską formą nazwy zawodu. Jednak różnice, zarówno w przypadku zawodów sfeminizowanych, jak i (co stanowiło dużą niespodziankę), zawodów zmaskulinizowanych, okazały się stosunkowo niewielkie (ok. 3\%). Forma męska nazwy zawodu była zdecydowanie częściej wskazywana jako bardziej prestiżowa (w jednym z czterech wymiarów statusu) jedynie w przypadku zawodów neutralnych. Opisaną sytuację obrazuje rys 2.

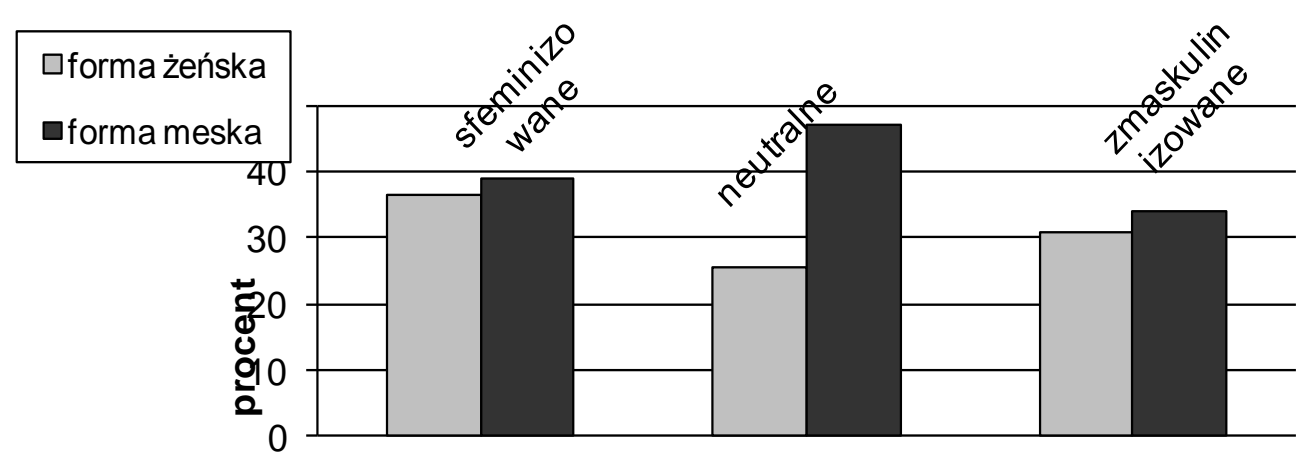

\section{Rys. 2 Status a poziom sfeminizowania lub zmaskulinizowania zawodu}

Podobnie jak w przypadku danych ogólnych, pod uwagę wzięte tu zostały jedynie te wskazania, w których badane osoby jednoznacznie mówiły o przewadze którejś z osób w danym wymiarze obserwowalnego porządku władzy i prestiżu. Widać więc, że o ile w przypadku

\footnotetext{
${ }^{6}$ Stwierdzenie to oparte jest na licznych rozmowach przeprowadzonych przez autorkę, w których rozmówcy zawsze jednoznacznie wskazywali, że to męskie nazwy cieszą się wyższym statusem, w tym także na wypowiedziach badanych osób, które jednak zostaną zanalizowane osobno.
} 
zawodów sfeminizowanych i zmaskulinizowanych, na wyższy status którejś z nazw wskazuje około jedna trzecia badanych (nieco więcej w przypadku zawodów wykonywanych w większości przez kobiety), w przypadku zawodów neutralnych - formy żeńskie za bardziej prestiżowe uznane zostały jedynie w co czwartym przypadku, zaś formy męskie - w blisko połowie z nich.

Wynik ten wydaje się dość interesujący i zastanawiający. Na podstawie wypowiedzi badanych dotyczących żeńskich nazw zmaskulinizowanych zawodów, jak na przykład: pracuje $w$ męskim gronie, wydaje mi się, że może być tam jedyna kobietq i chce to podkreślić, nawet ma takie trochę feministyczne zacięcie ${ }^{7}$ lub celowo podkreśla to, że jest kobieta, uważa, że w ten sposób może przyciagnać (...) klientów można przypuszczać, że osobom wykonującym męskie zawody, a posługującym się żeńskimi formami ich nazw, przypisuje się świadome ich używanie, jako formy przekazu pewnych zdolności i umiejętności. $Z$ tym wiąże się przypisywanie im wyższego statusu niż osobom, które wykonując zawody zmaskulinizowane używają nazw w rodzaju męskim, którym przypisuje się raczej wykonywanie danego zawodu z konieczności lub na przykład na skutek odziedziczenia zakładu pracy po ojcu. Jednak jest to tylko hipoteza, której potwierdzenie lub odrzucenie wymagałoby przeprowadzenia bardziej szczegółowych badań.

Po uwzględnieniu wskazań dotyczących równego statusu obu nazw zawodów na uwagę zasługują szczególnie dwie istotne różnice. Po pierwsze istotne wydaje się podkreślenie, że w przypadku wszystkich rozważanych nazw zawodów, w ponad połowie przypadków status nazw żeńskich był wyższy lub równy statusowi nazw męskich. Zatem częściej był on uznawany za wyższy lub równy, w stosunku do statusu nazw męskich, niż za niższy od niego. Można więc stwierdzić, że (przynajmniej w badanej w tym przypadku grupie osób), w żadnej $\mathrm{z}$ grup zawodowych żeńska nazwa zawodu nie wpływa w sposób istotny na obniżenie statusu osoby, która się nią posługuje.

Drugim faktem, który zasługuje na uwagę, jest znaczący wzrost liczby wskazań na nazwy żeńskie w stosunku do nazw męskich. Przyrost ten związany jest ze wskazaniami, które ogólnie mogą zostać zakwalifikowane do kategorii „dla świętego spokoju”. Najwięcej takich stwierdzeń pojawiło się $\mathrm{w}$ przypadku zawodów zmaskulinizowanych - ok. 8\% wszystkich odpowiedzi. $\mathrm{O}$ jeden procent mniej takich wypowiedzi pojawiło się $\mathrm{w}$ przypadku zawodów wykonywanych w większości przez kobiety, zaś dla zawodów neutralnych było to prawie 5\%. Zatem to w przypadku zawodów neutralnych respondentki najrzadziej podawały odpowiedzi, które zakwalifikowane zostały do kategorii „dla świętego spokoju”. Atrybucja cech charakterologicznych (prezentowana szerzej poniżej) pozwala przypuszczać, że to zawody neutralne w najmniejszym stopniu wywoływały skojarzenia związane $\mathrm{z}$ takimi cechami, które ostatecznie decydowały o przewadze w którymś z wymiarów obserwowalnego porządku władzy i prestiżu, a równocześnie nie są bezpośrednio związane $z$ kategorią statusu. Tak więc, można przyjąć, że to w przypadku grupy zawodów neutralnych badane miały najmniej podstaw, by uznawać, że któraś ze stron ustępuje „dla świętego spokoju”.

\subsection{Status a wiek osób badanych}

Wpływ czynników związanych z warunkami socjalizacji na postrzeganie żeńskich i męskich nazw zawodów stał się podstawą do przypuszczenia, że wiek respondentów może stanowić czynnik różnicujący to postrzeganie. Również w tym przypadku wyniki badań okazały się zaskakujące.

Procentowy udział wskazań na wyższy status jednej $\mathrm{z}$ form we wszystkich wskazaniach z podziałem na poszczególne grupy wiekowe respondentek ilustruje rys. 3 .

\footnotetext{
${ }^{7}$ Kursywą podano cytaty z wypowiedzi osób badanych.

${ }^{8} \mathrm{~W}$ prezentowanej tu analizie do tej kategorii zaliczono wypowiedzi odnoszące się do sytuacji, w których jednoznaczne rozstrzygnięcie o przewadze którejś z osób było trudne dla respondentów ze względu na porównywalny status obu nazw, zaś o ostatecznej przewadze $\mathrm{w}$ którymś $\mathrm{z}$ wymiarów decydowały cechy charakterologiczne (przypisane przez respondentów), nie związane bezpośrednio ze statusem.
} 


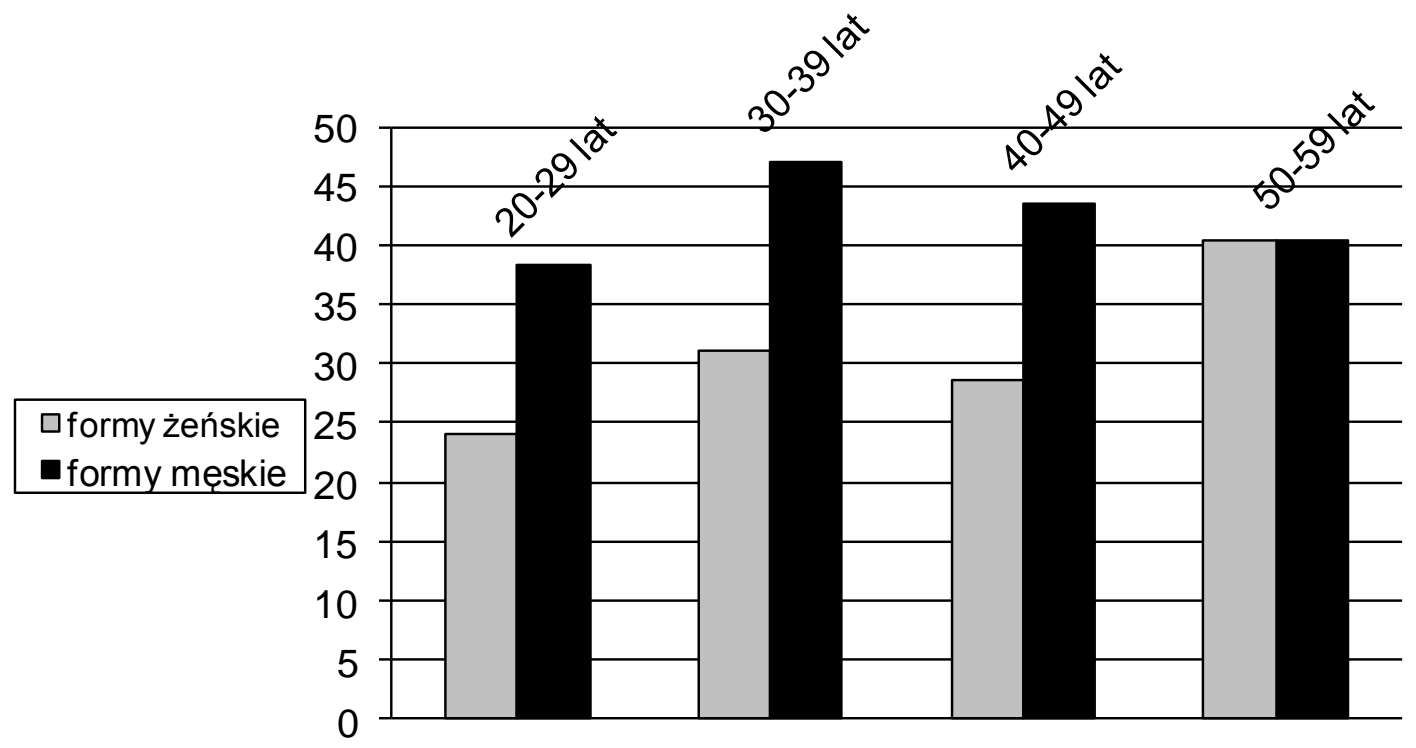

\section{Rys. 3 Status a wiek osób badanych}

We wszystkich grupach wiekowych różnica między procentem przypadków, w którym wyższy status przypisano męskim nazwom zawodów, a tymi, w których przypisano go żeńskim formom, wynosi ok. $15 \%$. Wyjątek stanowi tu najstarsza grupa wiekowa, a więc osoby powyżej pięćdziesiątego roku życia.

Wyniki uzyskane $\mathrm{w}$ badaniach wydają się interesujące $\mathrm{z}$ dwóch przyczyn. Po pierwsze zaskakuje stosunkowo niski prestiż przypisywany żeńskim nazwom zawodów przez najmłodszą grupę respondentek, zwłaszcza, że można było przypuszczać, że właśnie w tej grupie odsetek ten będzie najwyższy, ze względu na uwarunkowania społeczno-kulturowe, a więc przede wszystkim częste pojawianie się tematyki związanej z równouprawnieniem $\mathrm{w}$ mediach, a także zmieniający się wizerunek kobiety w społeczeństwie. Podejmując próbę wyjaśnienia tego zjawiska warto odwołać się do nieco innych danych. Dotyczą one procentowego udziału deklaracji o równym statusie obu nazw we wszystkich wskazaniach (rys 4).

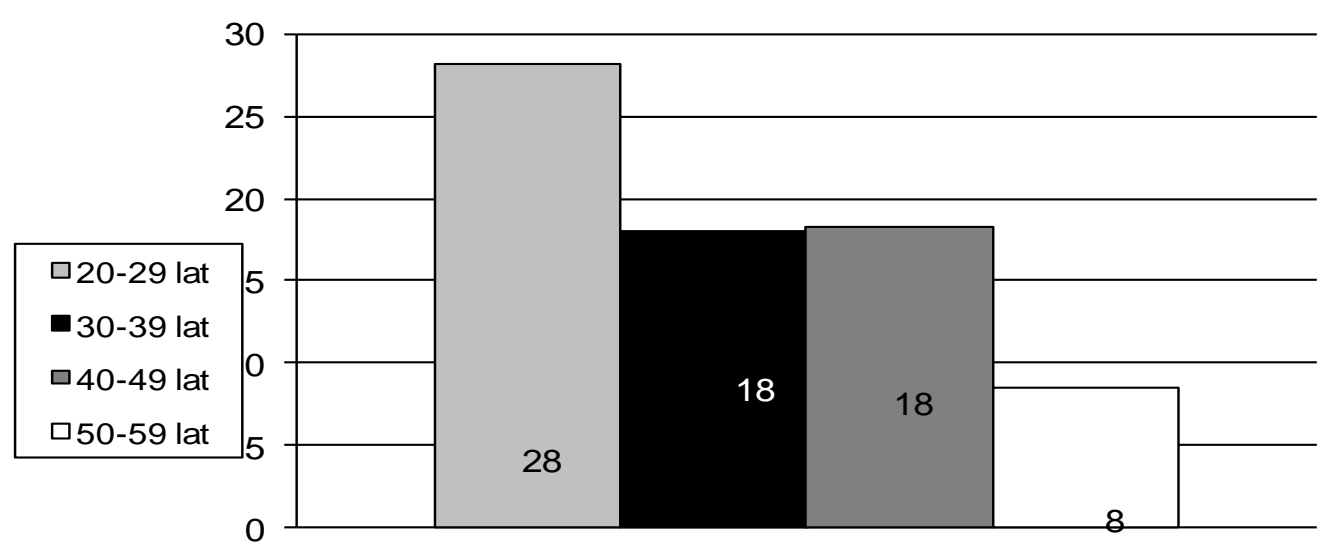

Rys. 4 Równy status obu nazw a wiek osób badanych

Widać więc wyraźnie, że liczba odpowiedzi wskazujących na równy status osób posługujących się obiema nazwami zawodów jest zdecydowanie najwyższa wśród najmłodszej grupy wiekowej. Na tej podstawie przypuszczać można, że współczesne warunki socjalizacji nie tyle wpływają na 
podniesienie statusu żeńskich nazw zawodów, ile sprawiaja, że status nazw w obu rodzajach ulega wyrównaniu. Tendencja ta pojawiła się przynajmniej w grupie osób biorących udział w prezentowanych tu badaniach.

Interesujący wydaje się również fakt, że to najstarsze badane najczęściej uznawały nazwy żeńskie za bardziej prestiżowe od męskich. W przypadku tej grupy liczba wskazań na wyższy status nazw męskich i na wyższy status nazw żeńskich jest prawie taka sama. Hipoteza wyjaśniająca to zjawisko opiera się na zmianach norm językowych dotyczących użycia nazw męskich. W latach 70., a więc w okresie, w którym badane osoby rozpoczynały swoje życie zawodowe, wydawnictwa normatywne zalecały używanie nazw żeńskich, w przypadku, gdy są one dobrze utrwalone w języku (Satkiewicz i in. 1973). Przypuszczać więc można, że badanym osobom nazwy żeńskie użyte w stosunku do kobiet mogły wydać się poprawne, czy też zgodne z normą, co z kolei wpłynęło na podniesienie ich prestiżu. We współczesnych opracowaniach normatywnych zaleca się używanie form męskich, bez względu na to, czy istnieją utrwalone formy żeńskie (Jadacka 2005), co może wyjaśniać ich niższy prestiż w pozostałych grupach wiekowych.

Jednak zarówno ze względu na małą liczebność i niereprezentatywność próby, jak i jedynie hipotetyczny charakter powyższych wniosków, ostateczne ich przyjęcie lub odrzucenie wymagałoby przeprowadzenia bardziej szczegółowych badań.

Po uwzględnieniu wskazań dotyczących równego statusu obu nazw, a także tych, które zaliczyć można do wspomnianej powyżej kategorii „dla świętego spokoju”, warte uwagi wydają się w tym przypadku dwa zjawiska. Po pierwsze bardzo duży udział wskazań na równy status obu form w najmłodszej grupie wiekowej, który został już omówiony powyżej. Drugim zjawiskiem wartym uwagi wydaje się znaczny wzrost wskazań zaliczonych do kategorii „dla świętego spokoju" w przypadku nazw żeńskich w dwóch najstarszych grupach wiekowych. Podczas gdy w dwóch pierwszych grupach wynosi on około $3 \%$, w grupie osób po 40 ., a przed 50. rokiem życia wzrasta on do prawie $7 \%$, zaś w najstarszej grupie wynosi już ponad $10 \%$. Jak dokładniej pokaże prezentowana poniżej analiza jakościowa, wielokrotnie osobom posługującym się męskimi nazwami zawodów przypisywano więcej cech męskich. Część badanych wyrażała swoje skojarzenia wprost, w sformułowaniach typu mi się to bardziej z takim męskim typem kojarzy lub ta osoba będzie miała więcej takich typowo męskich cech. Zatem, jeśli przyjąć, że osobom posługującym się nazwą zawodu $\mathrm{w}$ rodzaju męskim przypisywano również zachowania interakcyjne typowe dla mężczyzn, zaś w rodzaju żeńskim - typowo kobiece, omawiany tu wynik można wiązać ze zmieniającym się modelem rodziny, a tym samym relacjami między kobieta a mężczyzną. W partnerskim, egalitarnym modelu rodziny, który wydaje się być wzorcem dla osób z młodszych generacji, rzadkie są sytuacje, gdy ktoś ustępuje dla świętego spokoju lub z braku chęci do prowadzenia dyskusji. W bardziej tradycyjnym (a tym samym, jak można przypuszczać, charakterystycznym dla starszych z badanych osób) wyobrażeniu o rodzinie, to mężczyzna często bywa tym, który ustępuje trajkocącej kobiecie, żeby móc ze spokojem zagłębić się np. w lekturę ulubionego czasopisma. Można zatem przypuszczać, że taki typ relacji przełożony został na relacje między kobietami posługującymi się nazwami zawodów $w$ dwóch różnych rodzajach gramatycznych.

Jednak podobnie jak w przypadku wszystkich innych proponowanych tu wyjaśnień, ma ono jedynie charakter hipotetyczny, zaś jego potwierdzenie bądź odrzucenie wymagałoby przeprowadzenia pogłębionych badań, które pozwoliłyby dotrzeć do tych struktur świadomości badanych, które wpływają (lub nie) na projekcję typowych relacji między kobietą a mężczyzną na relacje badane w tej pracy.

\subsection{Status a sfeminizowanie bądź zmaskulinizowanie zawodu badanych osób}

Formułując problem badawczy uznano, że na status przypisywany poszczególnym nazwom zawodów wpływ może mieć nie tylko wiek respondentek, ale także ich środowisko zawodowe, a dokładniej poziom sfeminizowania bądź zmaskulinizowania zawodu, który wykonują. Zależność między tą zmienną a deklaracjami wskazującymi na wyższy status którejś z nazw zawodów zapreznetowana została na rys. 5 . 


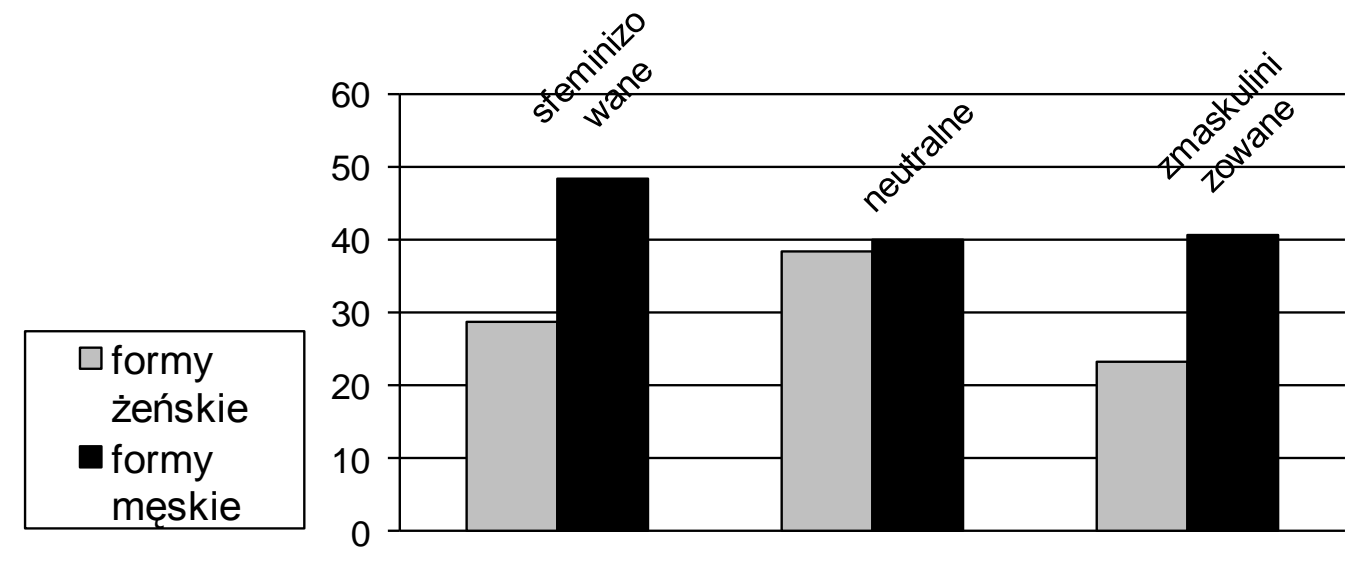

Rys. 5 Status a sfeminizowanie bądź zmaskulinizowanie zawodu badanych osób

Osoby posługujące się męskimi nazwami zawodów cieszyły się najwyższym statusem wśród osób wykonujących zawody sfeminizowane, zaś niższym i bardzo podobnym w przypadku respondentek będących przedstawicielkami zawodów neutralnych i zmaskulinizowanych. Z kolei nazwy żeńskie za bardziej prestiżowe uznawane były najczęściej przez osoby pracujące w zawodach neutralnych, a najrzadziej - w zawodach zmaskulinizowanych. Największe różnice między prestiżem przypisywanym formom męskim i żeńskim pojawiły się w grupie osób wykonujących zawody sfeminizowane, zaś najmniejsze, w przypadku osób wykonujących zawody neutralne pod względem płci.

Dane te wydają się dość niejednoznaczne, a tym samym trudno sformułować hipotezę, która mogłaby wyjaśnić taki, a nie inny rozkład statusu ze względu na poziom sfeminizowania bądź zmaskulinizowania zawodu respondentów. Wydaje się, że aby dokładniej wyjaśnić to zagadnienie, konieczne byłoby przeprowadzenie badań z udziałem większej liczby przedstawicieli każdej z grup zawodowych - pozwoliłoyby one przede wszystkim stwierdzić, czy uzyskane dane sa odzwierciedleniem tendencji w całej populacji, czy może na uzyskane wyniki wpłynął jakiś czynnik zaburzający, jak na przykład indywidualna historia zawodowa badanych osób.

Po uwzględnieniu odpowiedzi wskazujących na równy status obu nazw, a także tych, które mogą zostać zakwalifikowane do wspomnianej już kategorii „dla świętego spokoju”, wśród zebranych danych na szczególną uwagę zasługują dwa wskaźniki. Po pierwsze znacznie niższy udział wskazań dotyczących równego statusu obu zawodów wśród respondentek wykonujących zawody zaklasyfikowane jako neutralne. Podczas gdy zarówno dla zawodów sfeminizowanych jak i zmaskulinizowanych jest to ponad jedna piąta wskazań, w przypadku zawodów neutralnych jest to jedynie ok. 14\%. Wnioskować z tego można, że przynajmniej wśród osób, które brały udział w prezentowanych tutaj badaniach, osoby, które pracują w zawodach o równowadze płci wśród ich wykonawców, wykazują największą skłonność do jednoznacznej atrybucji wyższego statusu którejś z form nazw zawodów. Być może wiąże się to z częstym obcowaniem zarówno z formami męskimi jak i żeńskimi nazw zawodowych, a co za tym idzie, posiadaniem jednoznacznego zdania na temat wyższego prestiżu którejś z nich. Wynik ten jest tym bardziej zaskakujący, że zdawać by się mogło, że właśnie osłuchanie i częste obcowanie z obiema formami nazw zawodów będzie prowadzić do zanikania różnic $\mathrm{w}$ ich postrzeganiu. Dlatego też bardzo interesujące byłoby 
zbadanie, czy tendencja ta występuje w całej populacji, czy też uzyskany tu wynik związany jest $\mathrm{z}$ jakimiś anomaliami występującymi w badanej grupie.

Drugim interesującym zjawiskiem jest znacznie większy udział wskazań zaklasyfikowanych do kategorii „dla świętego spokoju” wśród osób wykonujących zawody zdominowane przez mężczyzn. W przypadku żeńskich form nazw zawodów wskaźnik ten jest blisko trzy razy wyższy, niż we wszystkich pozostałych kategoriach zawodowych. A więc to respondenci wykonujący zawody, w których przeważają mężczyźni najczęściej wskazywali na sytuację, w której kobieta posługująca się męską formą nazwy zawodu ustępuje pola w interakcji „dla świętego spokoju” osobie, która posługuje się nazwą zawodu w rodzaju żeńskim. Jako przyczynę takich zachowań badane $\mathrm{z}$ tej grupy wskazywały na przykład większy dystans do sprawy [rozwiazywania powierzonego zadania], stwierdzenie, że szkoda strzęić języka lub brak chęci by marnować czas na takq dyskusję. Jednak odkrycie, dlaczego atrybucja taka występuje najczęściej wśród osób wykonujących zawody zmaskulinizowane, a także czy jest ona faktycznie charakterystyczna dla tej populacji, wymagałoby przeprowadzenia osobnych badań.

\section{Analiza jakościowa}

\subsection{Typologia postaw}

Halina Jadacka w 2001 roku napisała, że z używaniem nazwy zawodu w rodzaju żeńskim wiąże się „odczuwanie żeńskiej profesji jako gorszej lub mniej poważnej” (por. Jadacka 2005). Jednak zgromadzone $w$ prezentowanych tutaj badaniach dane empiryczne zdają się wskazywać na istnienie zróżnicowanych i znacznie mniej jednoznacznych odczuć wobec żeńskich nazw zawodów. Owo zróżnicowanie pozwala na wyłonienie pewnych typów postaw. W analizowanych wywiadach badane osoby w różny sposób reagowały na prezentowane im żeńskie i męskie nazwy zawodów. Pojawiające się opinie były bardzo zróżnicowane - od osób, które prawie nie dostrzegały różnic między kobietami posługującymi się męską lub żeńską nazwą zawodu, aż po silnie emocjonalne określenia jednej z nich takie jak dziwaczka czy ginekolog z aspiracjami na pedofila. Na podstawie mozaiki postaw i odczuć pojawiających się w zebranym materiale podjęto próbę wyróżnienia pewnych typów postaw, a więc powtarzalnych reakcji na prezentowane bodźce, w których można byłoby dostrzec pewien wzorzec.

Typy te są w zamierzeniach typami idealnymi w rozumieniu Webera, czyli skonstruowanym przez badacza instrumentem służącym strukturalizacji amorficznej per se rzeczywistości (Szacki 2002: 465). Z jednej strony więc typy idealne pomagają w porządkowaniu i rozumieniu rzeczywistości, $\mathrm{z}$ drugiej na zawsze pozostają tylko (a może aż) konstruktami powstałymi w umyśle badacza. Zwraca na to uwagę Szacki: „typu idealnego się nie odkrywa w empirycznej rzeczywistości, typ idealny się tworzy, ażeby tę rzeczywistość badać i rozumieć, nie oczekując wszakże, iż będzie z nim kiedykolwiek całkowicie zgodny" (Szacki 2002).

Stworzona w tej pracy typologia, choć oparta na materiale empirycznym, jest więc konstrukcją teoretyczną, której zadaniem jest przede wszystkim ukazanie złożoności i zróżnicowania postaw wobec nazw zawodów w rodzaju męskim i żeńskim używanych przez kobiety.

\subsubsection{Typologia postaw}

\section{RÓWNOUPRAWNIONE ${ }^{9}$}

Dla Równoupranionych rodzaj gramatyczny nazwy zawodu nie ma żadnego znaczenia. Snując przypuszczenia na temat cech osoby, której wizytówce się przyglądają, Równouprawnione posługują się stereotypami dotyczącymi zawodów lub własnymi skojarzeniami związanymi z imieniem danej osoby. Posługując się terminami bergerowskimi - rodzaj gramatyczny nazwy zawodu nie prowadzi do aktywacji jakiegoś stanu oczekiwań.

\footnotetext{
${ }^{9}$ Ze względu na fakt, że w badaniach brały udział jedynie osoby płci żeńskiej, nazwy poszczególnych typów postaw zostały podane w rodzaju żeńskim.
} 


\section{EMOCJONALNE}

Rodzaj gramatyczny nazwy zawodu silnie wpływa na emocje. Dla Emocjonalnych stanowi on przede wszystkim informację, czy dana osoba będzie sympatyczna, czy może wręcz przeciwnie, względnie czy $w$ jakiś sposób odstaje ona od normy. Używają one wielu słów o silnym zabarwieniu emocjonalnym. Jednak emocje te nie są związane ani z przypisywanym statusem ani $\mathrm{z}$ atrybucją cech stereotypowo męskich lub żeńskich.

\section{STEREOTYPOWE}

W ich wypowiedziach można znaleźć podręcznikową listę stereotypowych cech żeńskich i męskich, przy czym przypisywane są one zawsze według tego samego klucza: nazwa w rodzaju żeńskim - cechy żeńskie, nazwa w rodzaju męskim - cechy typowo męskie. Dla Stereotypowych nauczycielka jest zawsze bardziej gadatliwa, serdeczna, otwarta na ludzi, zaś kobieta podpisująca się „nauczyciel” - konkretna i bardziej zdystansowana. Podział po linii nazwa żeńska - osoba bardziej kobieca, nazwa męska - osoba o cechach stereotypowo męskich, jest bardzo wyraźny. Towarzyszą mu także atrybucje statusu, zgodne z kierunkiem zaproponowanym przez Jadacką a więc formy męskie są postrzegane jako bardziej prestiżowe.

\section{SEMIOTYCZKI}

Dla Semiotyczek rodzaj gramatyczny nazwy zawodu to przede wszystkim ukryta informacja formułowana przez osobę, która nazwy tej używa. W przypadku nazw zawodów może to być chwyt reklamowy, sposób na podkreślenie swojej kobiecości, a nawet forma demonstrowania feministycznych poglądów. Semiotyczki zakładają że forma nazwy zawodu, której używa kobieta, jest komunikatem, który tworzy ona świadomie i z pewną z góry założoną intencją.

\subsubsection{Typy w praktyce}

Jak już wspomniano powyżej, typy te są konstrukcjami teoretycznymi stworzonymi na podstawie materiału empirycznego. Oznacza to, że wśród badanych osób zaobserwowano występowanie opisanych powyżej postaw, jednak nie w „czystej” postaci, a jedynie w postaci przewagi pewnych, z punktu widzenia badacza znamiennych, zachowań nad innymi. Dlatego też interesujące wydaje się przełożenie opisanych wyżej konstruktów teoretycznych na praktykę badawczą - z jednej strony przez wskazanie na charakterystyczne wypowiedzi, które wpłynęły na wyłonienie tych typów, a następnie, wtórnie, na zaklasyfikowanie do nich poszczególnych badanych osób. Z drugiej zaś strony przez zaprezentowanie częstości występowania poszczególnych typów postaw w badanej grupie.

\section{RÓWNOUPRAWNIONE}

Pojawiają się deklaracje wprost takie jak nie widzę żadnych różnic albo one będa takie same lub też bardzo wyraźne jest oddziaływanie imienia na wypowiadaną opinię, między innymi w sformułowaniach typu Kasie to sq leniuchy śmierdzqce albo te Matgorzaty (...) to sq takie strasznie ważne na swoich stanowiskach. Również w wypowiedziach dotyczących cech czy zachowań poszczególnych osób nie widać żadnego wzorca związanego z rodzajem gramatycznym nazwy zawodu, który dość wyraźnie pojawia się w przypadku pozostałych typów postaw.

Przewagą tego typu postaw charakteryzowały się dwie z badanych osób. Wśród innych respondentów postawa ta występowała dość sporadycznie. Na przykład w związku z silnym skojarzeniem z jakimś imieniem - imię Karolina, jakoś tak od razu, może dlatego, że (...) znałam Karoliny młodsze ode mnie, [kojarzy mi sie] jako Karolinka. Karolinka jako dziecko. W innym przypadku brak różnic między prezentowanymi osobami thumaczony był środowiskiem zawodowym respondenta - miałabym takie same odczucia (...) może to wynika stad, że mam kontakt z ta grupq zawodowa $i$ często zwracam sie do kobiet [używajac żeńskiej formy nazwy zawodu]. Zdarzało się też, że brak dostrzegania różnic był deklarowany wprost, jednak bez uzasadnienia jego wystapienia, jak na przykład: bardzo podobne skojarzenie, takie samo, identyczne chyba. Jednak również takie zachowania pojawiały się raczej sporadycznie u pozostałych respondentów.

\section{EMOCJONALNE}

Z przedstawianych przez Emocjonalne opisów poszczególnych kobiet dowiedzieć się można przede wszystkim, czy chciałyby mieć z taką osobą do czynienia: każdy chciatby trafić do jej sqdu, a także: nie nadaje się do pacjenta, a także czy jest ona godna sympatii - sympatyczna, rozmawia 
się z niafajnie. W wypowiedziach Emocjonalnych ważne miejsce zajmuje również to, co definiują one jako „normę" i miejsce opisywanej osoby względem tej normy - jest to widoczne w sformułowaniach takich jak zwykła, normalna, dziwaczka etc.

Dwie $\mathrm{z}$ badanych osób wykazywały się zdecydowaną przewaga postaw tego typu. U jednej $\mathrm{z}$ nich pozytywne nacechowanie emocjonalne wiązało się $\mathrm{w}$ większości $\mathrm{z}$ żeńską formą nazwy zawodu, natomiast u drugiej nie miało jednego, określonego kierunku. Wśród innych respondentów ta postawa pojawia się na przykład na skutek własnych doświadczeń związanych z osobą wykonującą dany zawód - przychodzi mi na myśl [osoba] jakq mam w firmie (...) okropna. Programowa zolza. Poza tego typu przypadkami deklaracje dotyczące emocji, jakie budziła prezentowana nazwa zawodu, pojawiały się dość rzadko.

\section{STEREOTYPOWE}

O swoich przekonaniach mówią wprost ta forma żeńska [kojarzy mi sie] automatycznie w tych kategoriach bardziej kobiecych, a także wyraźnie jest to widoczne w wymienianych przez nie cechach charakteru. Osoby posługujące się żeńskimi formami nazw zawodów są więc bardziej kobiece, cieplejsze, bardziej gadatliwe, a także miewają skłonność do plotkowania. Zaś o kobietach, które posługują się nazwami zawodów w rodzaju męskim mówią że są bardziej męskie $w$ sposobie bycia, są ubrane $w$ spodnie i mają krótkie włosy. Wśród ich cech pojawia się konkretność, stanowczość a także na przykład zainteresowanie sportem lub zamilowanie do jazdy na rowerze, pływania, biegania i gier zespołowych. Podział w postrzeganiu poszczególnych osób jest też widoczny jeśli chodzi o kompetencję i status im przypisywany. Tak więc Stereotypowe uważaja, że kobiety, które posługują się męskimi nazwami zawodów lepiej wypetniaja swoje obowiazki, są lepsze w swoim fachu, a także zajmują wyższe stanowiska w hierarchii zawodowej (np. główna księgowa $v s$ jedna $\mathrm{z}$ księgowych w dużej firmie).

Ten typ pojawił się wyraźnie u trzech spośród badanych osób. Istotne wydaje się tu spostrzeżenie, że wszystkie one wykonują zawody zdominowane przez kobiety. Również inne badane osoby, opisując pewne zawody, postępowały według wzorca charakterystycznego dla Stereotypowych. Jednak przyjąć można, że w przypadku tej postawy szczególnie ważna jest konsekwencja w atrybucji cech żeńskich i męskich, zatem nie wydaje się słuszne zaliczenie tu osób, u których wzorzec „,nazwa w rodzaju żeńskim - cechy typowo żeńskie, nazwa w rodzaju męskim - cechy męskie" pojawił się zaledwie kilka razy.

\section{SEMIOTYCZKI}

Formułując przypuszczenia dotyczące charakterów i zachowań poszczególnych prezentowanych im osób mówią na przykład: osoba, która pracuje $w$ męskim gronie, jest tam jedyna kobieta $i$ chce podkreślić to, nawet ma takie trochę feministyczne zacięcie lub celowo podkreśla to, że jest kobieta, uważa, że $w$ ten sposób może przyciagnać [klientki]. A zatem zakładają, że użyta przez daną osobę forma zawodu jest sposobem na komunikowanie swoich poglądów lub świadomie używaną metodą marketingową. Wśród Semiotyczek pojawiają się jednak także stwierdzenia, które wskazuja, że przypuszczają one, że nazwa zawodu używana jest jako świadoma forma autoprezentacji: ta osoba chciałaby podkreślić, że (...) pomimo stereotypów (...) czuje się dumna z tego, co robi lub [osoba, która] dowartościowuje się przez to, że będzie mieć rodzaj męski na wizytówce.

Ten typ postawy występował najrzadziej wśród badanych osób. Najwyraźniej zaobserwowany został u jednej z nich, choć i w tym przypadku nie występował on w „czystej” postaci. Podobna atrybucja w przypadku kilku zawodów pojawiła się również u innego respondenta. Jednak pomimo rzadkości występowania takiej postawy, wydaje się ona dość charakterystyczna, a zarazem interesująca. Ciekawe wydaje się również, że wystapiła ona u osób z dwóch pierwszych grup wiekowych, które albo pracują naukowo, albo wciąż się kształcą.

Max Weber, uznawany za twórcę metody idealnotypologicznej, pisał o „przemijalności wszystkich konstrukcji typów idealnych, ale zarazem nieuchronności [tworzenia] ciągle nowych" (Weber 2002: 94). Uzasadniał to zależnością tworzenia pojęć w naukach humanistycznych od sposobu postawienia problemów. Zatem zaproponowana powyżej typologia postaw nie jest ani jedynym prawdziwym, ani, co więcej, jedynym możliwym sposobem patrzenia na różne postawy 
wobec nazw zawodów w żeńskim lub męskim rodzaju używanych przez kobiety. Jest jedynie propozycją której podstawowym celem jest ukazanie różnorodności tych postaw.

\subsection{Analiza charakterystyk poszczególnych zawodów}

Jednym z celów jakie zostały postawione w prezentowanych tutaj badaniach, było odnalezienie odpowiedzi na pytanie, czy jest różnica i - jeśli tak, to jaka - między tworzonym ad hoc wizerunkiem kobiety posługującej się męską nazwą zawodu i takiej, która używa nazwy w rodzaju żeńskim. Zaprezentowane tu $\mathrm{w}$ postaci narracji wizerunki kobiet pozwalają dostrzec najbardziej istotne $\mathrm{z}$ tych różnic.

„Badacz ma perspektywę tego, co bada i interpretuje wywiad z tej perspektywy” (Kvale 2004), zatem zaprezentowane tu opisy odzwierciedlają to, co zostało uznane za istotne i ważne z perspektywy opisywanego zagadnienia. Nie dają one ani pełnego obrazu tego, jaka jest stereotypowa pani nauczyciel lub pani nauczycielka, ani też nie dostarczają obiektywnych danych, na podstawie których można by formułować jakiekolwiek uogólnienia. Zapewniają jednak wgląd w świat przeżywany badanych osób, dają możliwość zaobserwowania różnic, których zapewne nie udałoby się poznać pytając na przykład: „czym różni się pani fryzjerka od pani fryzjer?”.

Pearce pisał, że język to: „zdecydowanie najpotężniejsze narzędzie wynalezione przez ludzi po to, by tworzyć światy społeczne" (Griffin 2004: 91). Zatem zaproponowany poniżej przegląd charakterystyk osób posługujących się poszczególnymi nazwami zawodów daje szansę odkrycia i zwiedzenia fragmentów tych światów.

\section{Nauczycielka/nauczyciel}

Pani nauczycielka uczy przeważnie przedmiotów humanistycznych, na przykład języka polskiego lub angielskiego. Może też pracować w klasach 1-3, ma wtedy dobry kontakt z dziećmi, potrafi sie wczuć $w$ te wszystkie dziecięce sytuacje. Jest bardziej ciepła i opiekuńcza niż pani nauczyciel. Potrafi postuchać, zrozumieć i przytulić każde dziecko. Ma bardzo duża wiedzę, jest dobrze wyksztatcona i przygotowana do tego zawodu. Stara się zażegnywać wszelkie konflikty, a także ma super kontakt z rodzicami swoich podopiecznych, jednak jeśli spotyka jakikolwiek opór to się mu poddaje. Jest przekonana, że wszystko wie, ma swoje racje i teorie na caly świat.

Ma okulary na nosie, jest ubrana schludnie, w czarny sweterek i krótka spódnice do kolan. Bywa przeciętna, szara, zwyczajna. Zazwyczaj jest samotna, starq pannq. Jeśli ma swoje dzieci, to jest w nich zakochana, jest typową Matka Polka.

Ma różny stosunek do swojej pracy zawodowej. Jest bardzo zaangażowana $w$ swoja prace, $w$ życie towarzyskie szkoty. Jest człowiekiem, który się spala. Ale może się też zdarzyć, że już trochę $w$ zawodzie jest, lubi to co robi, ale trochę ja to męczy. Czasami też nie wktada serca w swoją pracę. W szkole dobrze czuje się w takim kobiecym gronie pań nauczycielek. Poza praca lubi ogladać filmy i czytać ksiażki.

Pani nauczyciel pracuje przeważnie $w$ liceum, uczy przedmiotów ścistych albo wychowania technicznego. Cieszy się szacunkiem swoich uczniów, który stara się (...) zdobyć od samego poczatku. Dlatego ma tendencję, żeby trzymać ich krótko, ale też jest dobrze przygotowana do zajęć, żeby nikt nie mógt jej niczym zagiać i tym imponuje swoim uczniom. W kontaktach $\mathrm{z}$ uczniami jest raczej bardziej rygorystyczna, wymagająa i surowa, a także nie zażegnuje konfliktów, więc zdarza się, że przychodza rodzice i sq awantury. Mimo to z chęciq pojedzie $z$ uczniami na wycieczkę, ale niekoniecznie wchodzi z nimi w jakieś bliższe kontakty. Jest więc raczej kumpelka, a nie dobra ciocia, która mówi, że będzie dobrze. Zarówno w pracy, jak i poza nia, jest konkretna, zdecydowana, a także wie, czego chce i twardo stapa po ziemi. Jeśli ustępuje $\mathrm{w}$ dyskusji, to dlatego, że uważa, że to nie jest istotne, gra nie jest warta walki lub bo jest madrzejsza.

Jej stosunek do pracy bywa również ambiwalentny $-\mathrm{z}$ jednej strony idzie do pracy, robi to, co musi, wraca do domu, a z drugiej lubi wykorzystać każda lekcje właściwie, bez przepuszczania czasu. Natomiast czas wolny wykorzystuje na jakiś tam samorozwój, branie udziału w różnych kursach, ma szersze zainteresowania poza szkoła niż pani nauczycielka. Czyta ksiqżki sciencefiction. Swój raczej męski charakter podkreśla tym, że więcej chodzi w spodniach i nosi delikatny makijaż. 
Podsumowujac pani nauczycielka jawi się przede wszystkim jako osoba ciepła, łagodna i opiekuńcza. Do jej cech charakterystycznych należy także wrażliwość na uczucia i potrzeby innych oraz dobry kontakt z małymi dziećmi. Za to pani nauczyciel to osoba pewna siebie, skłonna do rywalizacji, ambitna i aktywna ${ }^{10}$. Zatem można uznać, że w przypadku tego zawodu rodzaj gramatyczny jest dość silnym nośnikiem skojarzeń związanych z płcią.

Drugim elementem, który zasługuje na uwagę, jest różnica w statusie obu pań. To w przypadku osoby posługującej się nazwą w rodzaju męskim pojawiają się skojarzenia takie jak szacunek i respekt. Również przypisywane jej miejsce pracy, a więc liceum, w przeciwieństwie do szkoły podstawowej, wydaje się być bardziej prestiżowym miejscem pracy. Na tę różnicę w statusie zwracały również uwagę same osoby badane: nauczyciel brzmi poważniej, tak dostojniej (...) dostaje na wejście 5 punktów więcej niż [nauczycielka] a także: lepiej kojarzy mi się ta forma męska i nauczyciel brzmi lepiej niż nauczycielka.

Można więc przyjąć, że pomimo dużego sfeminizowania zawodu nauczycielki/nauczyciela, większym prestiżem cieszy się nazwa męska. Z jednej strony kojarzy się ona $\mathrm{z}$ cechami przypisywanymi stereotypowo mężczyznom, $\mathrm{z}$ drugiej prowadzi do przypisania wyższego statusu kobiecie nią się posługującej.

\section{Wychowawczyni/wychowawca}

Pani wychowawczyni pracuje $w$ podstawówce albo $w$ przedszkolu, a co za tym idzie jest bardziej nastawiona na takie podejście do ucznia jak do dziecka, więc można o niej powiedzieć: taka mamuśka troszeczkę. Czasami bywa infantylna i szczebiotliwa, a także miewa skłonność, by wszystkich traktować jak dzieci i używać tylko zdrobnień. Jest lubiana przez uczniów, a oni wiedza, że można na niq liczyć. Nie wymaga nie wiadomo jakich tam rzeczy, ale myśli raczej o tym, aby swoich podopiecznych rozwijać na różne [sposoby]. Za tym idzie jej twórcze podejście do dzieci i autorskie sposoby postępowania.

Jej stosunek do pracy jest dość jednoznacznie pozytywny - nie tylko lubi swoja pracę i bardzo przejmuje się [nia], a także stara się bardzo pozytywnie [w nia] angażować, ale, co więcej, czuje wagę tego, co robi; oprócz gratyfikacji finansowej za petnienie funkcji sprawia jej to duża satysfakcję. Choć zdarza się także, że ma wąsa specjalizację, a wtedy uczy plastyki a dodatkowo jest wychowawczyniq albo wręcz, co gorsza, nie uczy, nie ma żadnego przypisanego przedmiotu, żadnej specjalności, tylko jest przypadkiem wychowawczyniq.

Zarówno w pracy, jak i poza nia, jest oddana i ciepła, a także bardziej pomocna i umiejqca przymrużyć oko na pewne rzeczy. Do tego ma więcej dobroci $w$ sobie [niż pani wychowawca]. W dyskusji jest mało rzeczowa, bardziej emocjonalna.

Jeśli ma rodzinę, to jej prywatne dzieci sq pępkiem świata, jednak możliwe jest także, że niewiele ma życia rodzinnego. Ubrana jest przeważnie schludnie i nie wyzywajaco. Słowem: dobra duszka.

Pani wychowawca jest osobą $w$ średnim wieku, ubraną w beże i brązy i przeważnie nosi spodnie. Jej droga do takiego zawodu była różna - być może została wychowawca, bo dali jej klase do wychowania, ale możliwe też, że jest wychowawca kolonijnym, a wtedy traktuje bycie wychowawcą nie jak powołanie, tylko jako sposób zarabiania pieniędzy. Raczej nie pracuje $\mathrm{w}$ szkole podstawowej, a $w$ liceum, gimnazjum, a nawet $w$ domach poprawczych czy tez takich ośrodkach, gdzie sq Trudni. Jest osobą $z$ dobrym kontaktem $z$ dzieciakami, choć nie jest takq mamuśka, jest partnerska, ale niekoniecznie koleżeńska, do tego pilnuje mocno dyscypliny. Jednak możliwe także, że stara się być kumplem dla tych uczniów, ale nie wchodzi $w$ ich sfere emocjonalna.

W życiu zawodowym i domowym jest bardziej opanowana i zrównoważona, a także konkretna, zdecydowana i energiczna. Stapa po ziemi mocnymi krokami. W dyskusji ustępuje, bo machnie w pewnym momencie rękq albo uzna, że nie ma co się tu rozdrabniać, a także widzqc, że

\footnotetext{
${ }^{10}$ Wszystkie wymienione tu $\mathrm{i}$ w kolejnych podsumowaniach cechy należą do cech przypisywanych odpowiednio stereotypowym kobietom i stereotypowym mężczyznom, których lista stworzona została na podstawie: Brannon 2002, Budrowska 2000, Aronson 2004.
} 
[oponentka] jak się czegoś uczepi (...) to będzie powoli drązyć jak woda skatę i żeby już skrócić tę droge przez mękę, to przystanie na [jej] wersję. W domu trzyma rodzinę w garści. Rzadzi. Ma także większy dystans do swoich prywatnych dzieci, do tych z pracy również niż pani wychowawczyni.

Jest $z$ dystansowana także do pracy, choć jest także wychowawcą $z$ dużym stażem, który jest fachowcem w dziedzinie swojej lekcji i dobrze wykonuje swój zawód. Jest poważna i wzbudza większy respekt.

Podsumowując: pani wychowawca to osoba, która umie radzić sobie w trudnych sytuacjach, jest niezbyt wrażliwa, aktywna, a także dość opanowana i pewna siebie. Z kolei pani wychowawczyni pracuje $\mathrm{z}$ małymi dziećmi i widzi w tym swoje powołanie i pasję. Jest osobą ciepłą, wrażliwa, łagodną i emocjonalną. Zatem rodzaj gramatyczny nazwy zawodu jest również w tym przypadku silnie kojarzony z cechami męskimi lub żeńskimi, o czym zresztą osoby badane mówiły również wprost: [wychowawczyni] bardziej $w$ kategoriach żeńskich mi się kojarzy automatycznie przez forme, natomiast [wychowawca] bardziej w kategoriach męskich.

Również różnice w statusie są tu dość wyraźne - pani wychowawczyni pracuje w szkole podstawowej i jest raczej mamuśkq. Respondenci mówiąc o niej również częściej używali formy zdrobniałej od jej imienia. Natomiast pani wychowawca pracuje ze starszą młodzieżą, a nawet $\mathrm{w}$ domu poprawczym. To ona wzbudza respekt. Taki stosunek do obu tych nazw jest również widoczny $\mathrm{w}$ bezpośrednich wypowiedziach respondentów: [wychowawczyni] brzmi troche niepoważnie, podczas gdy [wychowawca] - to brzmi zupetnie inaczej.

\section{Ksiegowa/ksiegowy}

Pani ksieggowa właśnie wrócita z urlopu macierzyńskiego z powrotem do pracy, a w związku $\mathrm{z}$ tym bardzo często myślami jest $w$ domu. Ponieważ ma szczęśliwe życie rodzinne, to ceni sobie popoludnie spędzone $z$ rodzinq. Jest osobą $w$ średnim wieku, jest wypielęgnowana i nosi buty na obcasie.

Zawodowo jest księgowq w jakiejś tam firmie, obstuguje pewnie jednego klienta. Dodatkowo ma ściśle określony zakres obowiazków i raczej pracuje od 7 do 15-tej, a także ma czas na obiadek w pracy. Ale mimo to, nawet jak je ten obiadek, to ona i tak udzieli rady, czyli jak się przychodzi do niej, to ona zawsze doradzi i zawsze powie, co i jak zrobić. Jest dobra księgowa, chociaż widziała siebie w innym zawodzie, jakoś bardziej zwiqzanym z ludźmi.

Jako człowiek, jest osobą, której po pierwszym kontakcie się nie zapamiętuje. Bywa pogodna, uśmiechnięta, otwarta na to, co sie dzieje na zewnatrz, ale bywa też chłodna i $w$ kontaktach $z$ ludźmi uważajaca na stowa. Podobnie jak pani księgowy jest osobą dobrze wykonujaca swoja prace, aczkolwiek może trochę gorzej niż ta pod względem takim merytorycznym.

Pani ksieggowy zajmuje dość wysoka pozycję, na przykład jest zastępczynia głównej księgowej lub ma, albo daży do tego, aby mieć własna kancelarię. Jej kompetencje są dość ambiwalentne $\mathrm{z}$ jednej strony dobrze wykonuje swój zawód, ale jest także możliwe, że siedzi w biurze i nie ma zielonego pojęcia na temat księgowości. Wtedy robi pięknq otoczkę do tego, że ma biuro.

Jej charakterystycznym rysem jest to, że jest otwarta na wszelkie nowości $w$ dziedzinie księgowości, a także stara się ciagle rozwijać. Poza tym bywa stateczna, poukładana, bardzo otwarta, bardzo dynamiczna, ale bywa też chtodna i zdystansowana. Może także być wygadana, rzeczowa, konkretna i mocno ambitna. Są jednak osoby, które twierdza, że jest dziwaczka, a także starq pannq. Wizerunek pani ksieggowy dopełnia fakt, że jej jedzenie to czarna kawa i papieros leżacy w jakiejś popielniczce.

Podsumowujac: pani księgowa to osoba mocno zaabsorbowana swoim życiem domowym, a także opiekuńcza i ciepła w kontaktach międzyludzkich. Zaś pani księgowy jest przede wszystkim osobą ambitną i aktywną. A zatem nadal zachowana zostaje tu tendencja do przenoszenia cech żeńskich przez żeńską formę nazwy zawodu, zaś cech męskich - przez męską. Jednak tendencja ta wydaje się słabsza i mniej wyraźna niż w opisanych powyżej przypadkach nauczycielki i wychowawczyni.

Różnice w statusie pomiędzy panią księgowy a panią księgową widoczne są przede wszystkim w pozycji w hierarchii, którą zajmują, a także w ich miejscu pracy. Podczas gdy pani księgowa obsługuje jednego klienta i ma ściśle określone obowiązki, pani księgowy pracuje w dużej firmie i ma aspiracje, by awansować. Taka różnica została również wyrażona przez jedną z respondentek 
wprost: [ksiegowa] brzmi trochę mniej poważnie. Jednak u innej $\mathrm{z}$ badanych osób to nazwa księgowy wywołała negatywne skojarzenia: anachronizm jakiś, w pierwszej chwili pomyślałabym, że to błąd na wizytówce. Zatem różnice w statusie pomiędzy formą żeńską a formą męską są widoczne i zachowują ten sam, co w opisanych powyżej przypadkach kierunek, jednak są mniej wyraźne, a także rzadziej wyrażane wprost przez respondentów.

\section{Potożna/potożny}

Pani położna jak wchodzi do szpitala to rozmawia z matkami $i$ z kobietami $w$ ciaży. Jest zaangażowana $w$ pracy i solidnie wykonuje swoje obowiqzki. Na swój zawód zdecydowata się świadomie i już przez jego wykonywanie chce w jakiś tam sposób stużyć pomoca, przynosić ulge $w$ cierpieniu kobietom. Jest więc osobą bardzo troskliwa, wyrozumiata, życzliwa, pomocna i uczynna. Innymi słowy, czuje jakaśs misję zwiazana [ze swoim zawodem].

Opiekuje się członkami swojej rodziny i przejmuje się tym, co się dzieje. Zarówno w pracy, jak i w domu jest ciepla, pogodna, uśmiechnięta. Do tego bywa także spokojna i wewnętrznie ustabilizowana. Jest osobą, która rozsiewa takie ciepło wokót siebie, a jeśli się do niej przyjdzie w niedziele to ma zawsze jakieś tam ciasto.

Pani położny może okazać się ginekologiem z aspiracja na pedofila. Jej kompetencja zawodowa jest dość wysoka - ma oczywiście wszystkie możliwe fakultety porobione z polożnictwa, a także posiada duża wiedzę i duże doświadczenie. A jednak mimo to możliwe, że tak naprawdę to pewnie nie umie nawet odebrać porodu. Do pacjentek zwykła zwracać się na przykład mówiąc: „nie krzycz babo, bo nie pierwsza rodzisz”. A zatem nie nadaje sie do pacjenta i traktuje go przedmiotowo.

W pracy i poza nią jest niedopasowana do rzeczywistości, ma skłonność by robić wszystko po swojemu i to nie zawsze zgodnie z przyjętymi regutami gry. Do tego jest zarozumiata, bardzo zdystansowana $i$ zupetnie nie emocjonalna, a także obcesowa, arogancka. Jest zapewne takim męskim typem, a być może nawet czuje się niezidentyfikowana z ptciq. Innymi słowy: baba wstrętna, a co więcej istnieje podejrzenie, że należałoby jq ubezwtasnowolnić.

Podsumowując: pani położna to osoba przede wszystkim ciepła, opiekuńcza, świadoma uczuć innych, a także czuła i zdolna do poświęcenia dla innych. Pani położny jest niezbyt wrażliwa i ukrywa emocje. Zatem, o ile w przypadku pani położnej dość wyraźnie widoczne są cechy typowej kobiety, pani położny wzbudza przede wszystkim negatywne emocje i negatywne skojarzenia. Dużo słabiej widoczne są w jej opisach cechy typowe dla stereotypowych mężczyzn.

Określenie położny używane w stosunku do kobiety budziło wśród respondentów wiele kontrowersji: przecież to nie po polsku lub coś się tej pani pomylito, a także dla mnie trochę dziwactwo. Część z nich nie była sobie nawet $\mathrm{w}$ stanie wyobrazić takiej osoby - forma, która $w$ ogóle nie przemawia do mnie.

Warto jednak zauważyć, że z jednej strony wyżej wymienione sformułowania nie dotyczą bezpośrednio statusu obu nazw, a $\mathrm{z}$ drugiej - to właśnie w przypadku pani położny pojawiają się takie cechy związane z prestiżem, jak duża wiedza czy ukończenie kilku fakultetów. A zatem pomimo, że nazwa ta budzi tak silne negatywne skojarzenia, połączone zostają z nią również cechy potocznie uznawane za prestiżowe.

\section{Fryzjerka/fryzjer}

Pani fryzjerka to ruda, wytapirowana kobieta z wielkimi dlugimi paznokciami, a do tego korzysta dużo z solarium. W sumie jest dość ładna. Jest uśmiechnięta i zadowolona, a także ciepta i otwarta. Bywa niepozorna i cichutka, trochę szara myszka. Przeważnie więcej stucha niż mówi, choć bywa też skrzyżowaniem szczebiotliwej z [osobq z] dystansem.

Jest fryzjerką od dtugich włosów i lubi kombinować z ułożeniem tych włosów. Raczej pracuje u kogoś, bywa pomoca fryzjera. Jej droga do zawodu fryzjera nie była zbyt wyboista - skończyta szkołe podstawowa $i$ po szkole podstawowej poszła do jakiejś szkoły fryzjerskiej, i właśnie skończyła to fryzjerstwo, $i$ w tej chwili zatrudniła się w jakimś takim zaktadzie o średniej renomie, ale dość solidnie wyposażonym. Chociaż być może jest mniej utalentowana od pani fryzjer, to bardzo szybko nawiqzuje kontakt ze swoimi klientami, jest więc bardzo kontaktowa, a przy tym nie natrętna, więc klientka ma okazję się przy niej wyciszyć, można powiedzieć zrelaksować z tego powodu, że się ostrzyże. Jednak nie ma fantazji i robi przeciętne fryzurki, a także za dużo jakichś własnych [pomysłów] nie wprowadza i przeważnie nie umie przekonać nawet do swojej fryzury. 
Poza pracą ma mało czasu na swoje życie osobiste, więc mieszka z rodzicami. Ale miewa także bardzo duże grono znajomych. Jeśli ma swoje mieszkanie, to bardzo lubi dużo takich bibelotów aniotków, świeczników itp.

Pani fryzjer bywa na mikroskale businesswoman. Przeważnie ma super odpicowany gabinet i pod sobq podwładne. Możliwe także, że kiedyś pracowała pewnie w jedynym zakładzie fryzjerskim, który byt w miasteczku, w którym ona mieszka, a z czasem stwierdzita, że akurat tyle ludzi przychodzi do tego fryzjera, że ona równie dobrze może założyć swój własny zakład, i będzie miała klientów. Prawdopodobnie ma wygrane wszystkie możliwie konkursy na fryzury, a ponieważ lubi sie trzymać $z$ facetami, to stara się także przypodobać poprzez zdobywanie nowych umiejętności w tym męskim gronie. Klienci wiedzą również, że jest odważna w obcinaniu włosów i jak do niej ktoś przyjdzie i będzie miat dtuższe włosy, to ona mu zaproponuje taka fryzure inna zupetnie od tej, która miat.

Jest osobą nie lubiqca dużo mówić i pilnujacq swojej pracy, a także zdecydowana, energiczna i bardziej w sposobie bycia męskq. Innymi słowy: wie, co robi i wie, czego chce. Jest mniej dostęna i może mniej nawiqzujaca kontakt z klientem od pani fryzjerki, ale jest bardziej fachowcem, przekonuje swoim profesjonalizmem i swoja rzetelnościq.

Poza pracą dba o swój wyglad, ale raczej o pielęnację swojego ciała, a nie żeby podkreślić swoja kobiecość. Ma sprawdzone, ale nie za duże grono przyjaciól, a w jej domu panuje większa surowość i widać, że lubi nowoczesna sztukę.

Podsumowując: pani fryzjerka to osoba rozmowna i ciepła, a także taktowna i raczej cicha. Pani fryzjer natomiast jest kobietą aktywną i ambitną, a także ma głowę do interesów i jest pewna siebie. Zatem również $\mathrm{w}$ tym przypadku rodzaj gramatyczny zawodu dość silnie przenosi stereotypy męskości i kobiecości, co zresztą zostało wyrażone wprost przez jedną z badanych osób: [pani fryzjer jest] bardziej w sposobie bycia męskq.

Różnice w statusie między obiema paniami widoczne są przede wszystkim w ich miejscu pracy: podczas gdy pani fryzjerka pracuje u kogoś, pani fryzjer ma swój zakład i kilku pracowników pod sobą. A zatem to osoba posługująca się nazwą zawodu w rodzaju męskim jest postrzegana, jako stojąca wyżej w hierarchii społecznej.

\section{Dozorczyni/dozorca}

Pani dozorczyni po prostu sprzata blok albo kamienice. Jednak jej klatka jest regularnie zamiatana, regularnie myta, a do tego stoja [tam] jeszcze jakieś kwiaty. Ale z drugiej strony, jak komuś banda wyrostków podpali wycieraczkę, albo przyniesie zdechłego szczura pod drzwi, to nie myśli o niej, tylko pójdzie zaraz do spółdzielni lokatorskiej. A ponieważ zazwyczaj unika konfrontacji, to, gdy ktoś nie wywiązał się ze swoich obowiązków dotyczących sprzątania klatki, to raczej pójdzie i sprzqtnie, bo widzi, że ktoś tam zapomina.

Jest typowa wszędobylska, a to znaczy, że musi wszystko dookoła wiedzieć, co u wszystkich sqsiadów: komu się urodziło dziecko, komu zdecht pies. Jednak ważne, że przeważnie robi to $w$ dobrej wierze i stara się wszystkim pomóc. Ale możliwe także, że wstydzi się swojej pracy i wtedy chodzi między mieszkańcami ze spuszczona głowa, uważajac się za kogoś gorszego.

Ponieważ zdarza się, że żyje życiem innych i jest trochę pozbawiona swojego życia osobistego, to bardzo lubi się spotykać ze starszymi osobami na pótpiętrze i przegadywać godzinami. Jest osobą mita i grzecznq, a także życzliwa i serdecznq, a jednocześnie dość spokojnq. Choć bywa również osobq energicznq, takq babq z ikrq, która robi dużo szumu wokót siebie. Przeważnie jest uśmiechnięta i pogodna.

Pani dozorca miewa różne kompetencje - być może urasta do rangi kogoś, kto zajmuje się tym domem troszkę bardziej niż tylko dba o higiene mieszkańców, jednak zarazem może też być portierka, ale jest też prawdopodobne, że dba o porzqdek, który jest zrobiony tylko odtad - dotad, co trzeba, a nie ma już takiego upiększania, wymyślania jakichśs różnych dodatków na tej klatce. Bywa także rzqdzacym cieciem, a wtedy nosi wysoko podniesiona głowe i to na zasadzie: „prosze mnie się kłaniać, bo ja jestem dozorca". Możliwe, że została dozorca, bo przejęła tę funkcję po swoim mężu.

Od pani dozorczyni różni ją kontakt z lokatorami. Jest zdystansowana i nie interesuje się plotkami i nigdy się nie uśmiecha. Innymi słowy to pani, co tylko „dzień dobry, przyniosłam tutaj rachunki". Jest także konkretna, bardziej wycofana i zamknięta, a także surowa, wymagajaca, 
oschta i małomówna. Ale bywa również aktywna lub stateczna i o tagodnym dość usposobieniu. Przeważnie jest uporzqdkowanq kobieta, która jest w stanie wszystko poustawiać, skontrolować. Możliwe, że lepiej wypetnia swoje obowiazki i bardziej skupia się na pracy, niż pani dozorczyni, ale nie angażuje się $w$ życie towarzyskie osiedla czy domu.

Podsumowujac: pani dozorczyni to przede wszystkim osoba rozmowna i ciepła w relacjach z innymi, jest też opiekuńcza i wrażliwa na potrzeby innych. Zaś pani dozorca jest opanowana i niezbyt wrażliwa. Ma również skłonności przywódcze, a także raczej ukrywa emocje. Zatem również w przypadku dozorczyni/dozorcy żeński lub męski rodzaj gramatyczny nazwy zawodu jest nośnikiem stereotypowych cech odpowiednio żeńskich lub męskich. Jednak uwagę zwraca fakt, że więcej cech typowych dla płci odnaleźć można w charakterystyce pani dozorczyni, podczas gdy opisy pani dozorcy zawierają dość często zaprzeczenia cech wymienianych u dozorczyni, nie będących jednak elementami stereotypu męskości - np. rozmowna i małomówna.

Obraz dotyczący statusu jest w tym przypadku dość ambiwalentny. Część respondentów przypisuje osobie posługującej się męską nazwą zawodu większe kompetencje, a tym samym wyższe miejsce w hierarchii społecznej, jednak inni są skłonni przypuszczać, że pełnią tę samą funkcję i to właśnie dozorczyni w jej ramach robi więcej. Również wypowiedzi wprost są dość niejednoznaczne - z jednej strony - dozorca bardziej poważny, a także generalnie dozorczyni gorsza niż dozorca. Ale z drugiej strony - dozorca - brzmi to jakoś sztucznie i takie napuszone jest. Zatem uzyskany w tym przypadku obraz statusu jest najbardziej niejednoznaczny spośród opisanych dotąd zawodów.

\section{Starościna/starosta}

Pani starościna bywa po prostu matżonka starosty, bywa też starościna grupy studenckiej, jednak możliwe jest również, że pełni jakaś funkcje społecznq. Jako żona pana starosty jest po prostu żonq przy mężu. Możliwe, że prowadzi jakaśs tam na mała skale działalność charytatywnq, ale przede wszystkim dobrze opiekuje się domem, dziećmi. Gdy bywa starościną grupy lub roku ma dobre kontakty $z$ kadra profesorska, a także jest bardziej pyskata, niż elokwentna, ale w pozytywnym tego słowa znaczeniu. Jest również przebojowa, energicznq dziewczyna, a zarazem średniq studentka, jeżeli chodzi o wiedze teoretycznq. Gdy rozmawia z wykładowcami, oni na wszystko się zgadzaja, mimo że [ona] zupetnie nie ma racji. Jest także żywa i jakaś taka szybciutka, obrotna.

Kiedy jest panią starościną na przykład powiatu, gabinet ma urzqdzony tak, że odnosi sie wrażenie, jakby weszło się do domu babci. Jest otwarta na problemy innych i to wtaśnie do niej garna [sie] ludzie, bardziej niż do pani starosty. Jest także pogodna i życzliwa. Bardziej niż pani starosta wczuwa się w sytuację, bardziej jest otwarta dla ludzi, chce pomóc. W dyskusji, gdy chce kogoś do czegoś przekonać, potrafi użyć lekkiej manipulacji kobiecej. Można o niej powiedzieć: gospodyni. Bywa również kobieta sukcesu, która jest jednak skromna i uczciwa, ale także uparcie daży do swojego obranego celu. Ponieważ tak to ciepło brzmi ta starościna to bardzo możliwe, że ma mity, fajny koczek.

Pani starosta również bywa starostą grupy, choć rzadziej niż pani starościna. Jest wtedy średnio sympatyczna $w$ kontaktach międzyludzkich. Generalnie pójdzie, załatwi, dowie się, przyszykuje, ale zrobi to dlatego, że musi. Choć możliwe także, że jest osobą $z$ dużym temperamentem i takq bardzo aktywnq.

Zdecydowanie częściej jest starostą powiatu - wtedy zajmuje się sprawami dotyczqcymi dróg. Jest konkretna, rzeczowa, wymagajaca, żeby ludzie, którzy jej podlegaja, wykonywali zadania im przydzielone, a także kompetentna, zdecydowana, dażaca do z góry ustalonych celów. Bywa, że ludzie niekoniecznie do niej z jakimiś problemami swoimi chca iść, ponieważ jest bardziej nastawiona na siebie i oficjalna. Jednak możliwe także, że stara się zawsze być dla wszystkich i interesuje się wszystkimi osobami, które do niej pisza, czy przychodza, czy dzwoniq z jakimiś tam problemami czy sprawami, ale nawet wtedy pracuje do [wyznaczonej] godziny $i$ stara sie nie zostawać dużej. Przeważnie jest zaradna, twarda i pracowita. A do tego potrafi zarzadzać i szybko podejmuje decyzje. Zapewne jest też bardziej fachowa od pani starościny. Możliwe także, że niekoniecznie na tym stanowisku będzie chciała poprzestać, bo może jej się spodobać tego rodzaju praca, kariera. Niektórzy mówią też, że to baba w spodniach, garniturze, uniformie, która pilnuje swojego stotka. 
Podsumowujac: u pani starościny dominują cechy takie jak ciepło, wrażliwość na uczucia i potrzeby innych, a także gotowość do poświęcenia i opiekuńczość. Z kolei pani starosta jest osobą dość ambitną i aktywną. Ma skłonności przywódcze i jest raczej niezbyt wrażliwa. Jednak w przypadku tego zawodu warto zwrócić uwagę, że gdy jest mowa o staroście bądź starościnie powiatu, podział na cechy męskie i żeńskie wydaje się znacznie bardziej wyraźny, niż w przypadku starosty i starościny grupy.

Ze względu na pojawienie się różnych funkcji przypisywanych osobie starościny/starosty, jednoznaczne określenie różnic w statusie między tymi formami wydaje się dość trudne. Jednak istotne wydaje się, że badane osoby przypisywały bardziej prestiżową funkcję starosty powiatowego częściej osobie, która posługiwała się męską formą nazwy zawodu. To również w odniesieniu do niej mówiły na przykład o większej kompetencji czy fachowości. Natomiast formułowane przez respondentów wypowiedzi wprost dają obraz dość ambiwalentny. Z jednej strony starościna to przerost formy nad treścia, z drugiej zaś jedna z badanych osób deklaruje: jak najbardziej wydaje mi się, że tutaj bym odmieniła to właśnie, jeżeli wybieramy staroste grupy, to starościna by byta.

\section{Krawcowa/krawiec}

Pani krawcowa to pani z matego zakładu, takiego osiedlowego, zajmujaca sie obciaganiem guzików, wszywaniem zamków, podwijaniem spodni. Możliwe też, że jest paniq siedzqca sobie $w$ domu, która szyje na miarę. Prawdopodobnie nie ma specjalnego wyksztatcenia, a krawcowa została, bo wychowała już dwie córki, zreszta bliźniaczki i nastapił taki okres, że mogła się zajać czymś dodatkowym, a w zwiazku z tym, że byta zaradna i miała dużo manualnych zdolności, właśnie wtedy zaczęła szyć.

Jest terminowa i skrupulatna, ale raczej nie ma swoich pomystów, więc dostaje gotowe projekty jak przychodzi do niej klientka to mówi jej, co ma zrobić, a ona mówi jej, czy to jest wykonalne czy nie. Natomiast jest kontaktowa i w związku z tym wie o tych swoich klientkach wszystko i tam się latwo jej zwierzaja ze swoich problemów. Można nawet powiedzieć, że seans $z$ paniq krawcowa jest równocześnie sesja terapeutycznq. W porównaniu z panią krawiec jest bardziej gadajqca, bardziej otwarta w stosunku do klientów, ale zdarza jej się, że niekoniecznie do końca poprawnie będzie wszystko zrobione. Pani krawcowa to kobieta w sukience i taka porzqdnie ubrana, która hołduje tradycyjnemu modelowi rodziny. Jest miła, sympatyczna i raczej taka spokojna. Ma coś takiego fajnego ciepłego w oczach.

Pani krawiec szyje garnitury, płaszcze i spodnie męskie. Innymi słowy uprawia ciężkie krawiectwo. Możliwe, że odziedziczyła zakład po ojcu lub przejęła [go] po mężu. Jeśli ma swój zakład, to jest raczej trudno kontaktowa, a dodatkowo chodzi z taśma na szyi, ze szpilkami wbitymi $w$ ramię na poduszce, $w$ okularach na pół nosa i wiecznie ze szpilkami w buzi mówi. Ale zdarza się również, że szyje tak taśmowo, nie w kontakcie z ludźmi lub pracuje $w$ większym zakładzie, a wtedy być może trochę aspiruje do tego, żeby zostać projektantem mody w jakimś tam stowa tego znaczeniu.

Z charakteru jest przeważnie spokojna i milczqca, wystuchuje cierpliwie oczekiwań klienta, ale bywa także konkretna i precyzyjna. Chociaż specjalnie się swoja praca nie przejmuje, to jest osobą dobrze wykonujacq swój zawód.

Podsumowujac: pani krawcowa obdarzona jest wieloma cechami typowymi dla stereotypowej kobiety - jest ciepła, rozmowna, emocjonalna, a także wrażliwa na uczucia innych. Natomiast pani krawiec nie posiada zbyt wielu cech typowo męskich - jej obraz budowany jest raczej na zasadzie kontrastu do obrazu krawcowej - rozgadana vs milcząca, krawiectwo lekkie vs krawiectwo ciężkie itp.

Kwestia różnic w statusie między osobami posługującymi się nazwą krawiec i nazwą krawcowa wydaje się dość trudna do rozstrzygnięcia. Z jednej strony przy opisie pani krawiec pojawiają się informacje o tym, że jest dobrym fachowcem, $\mathrm{z}$ drugiej jednak, z wypowiedzi respondentów wynika, że ma ona mniej klientów niż pani krawcowa. Również opinie wyrażane wprost świadczą raczej o niekorzystnym stosunku do kobiety, która używa nazwy krawiec: kobieta krawiec się nie podpisuje, a także krawiec brzmi dziwnie. Zatem wypowiedzi badanych osób można interpretować jako wskazujące na niewielką różnicę w statusie między panią krawiec a 
panią krawcową, przy równoczesnym dość negatywnym stosunku emocjonalnym do kobiety posługującej się nazwą krawiec.

\section{Woźna/woźny}

Pani woźna ma dwa oblicza. Może być pierwsza po dyrektorze. Wtedy wszystko wie, wszystkim chce zarzqdzić, jest osobą krzyczqca na wszystkich, dbajacq o porzqdek, do tego sprzata ciagle i pokrzykuje na dzieci. Ale może być też osobą nie narzucająca swojej osobowości i bardzo takq tagodna.

Przeważnie pracuje w szkole w małym miasteczku. Została woźna, bo objęła tę funkcje po swoim ojcu, który przez cate lata powojenne byt woźnym. Jednak wykonuje swój zawód z jakiejś tam konieczności, być może dlatego, że skończyła swoja edukację na szkole podstawowej. Można powiedzieć, że jest to kobieta na właściwym miejscu. Ponieważ przeważnie jest stara kobieta, starej daty, to przez lata pracy nauczyła się te dzieci obserwować i nauczyła się, że te pokolenia się w jakiś tam sposób zmieniaja i trzeba się nauczyć z tym żyć.

Uczniowie przeważnie lubia ja, żartuja z nia, zostawiaja jej rzeczy, tornistry, jak trzeba. Co więcej, zawsze ma na podorędziu papucie, a nawet przyklei plasterek kiedy trzeba. Dlatego aura wokót niej się roztacza $i$ wszyscy do niej lgnq. Jest osobą ciepta, zawsze sympatyczna $i$ uśmiechnięta. Raczej potrafi stuchać niż mówić. Zna wszystkie tajemnice szkoły, więc można o niej powiedzieć, że jest takim dobrym duchem szkoły. W porównaniu do pani woźny jest troszke weselsza dla dzieci, a także bardziej przystepna. Do uczniów bardziej podchodzi taka swoja dobrocia, ale z drugiej strony jak potrzeba to też nakrzyczy.

Poza szkołą uwielbia ogladanie 150-cio odcinkowych seriali telewizyjnych.

Pani woźny prawdopodobnie pracuje w liceum. Być może podpisuje się woźny, bo to dyrekcja kazała jej się [tak] podpisać. Jednak możliwe jest także, że podpisuje się ,, woźny” dlatego, że ten zawód zdecydowanie kojarzy jej się z czymś męskim mimo wszystko. Sama jest bardziej męska, w związku z tym wykonuje fizycznie cięższe prace, na przykład - przerzuca węgiel. Bywa, że czuje się dumna z tego, co robi.

A jednak dzieci nie lubia jej i raczej mówiq o niej cały czas ,ten woźny”. Być może, dlatego, że jest nieprzystępna, bardziej oschła, ostra i obcesowa. Innymi słowy ma dystans do dzieci i ani ta młodzież się z niq nie spoufala, ani ona sie też nie stara jakoś do tej młodzieży dotrzeć. Również $\mathrm{w}$ kontaktach $\mathrm{z}$ innymi pracownikami szkoły zachowuje duży dystans, to znaczy nie wchodzi $w$ jakieś tam komitywy z ludźmi, które maja prowadzić do jakichś zwierzeń, czy opowiadania o sobie. Natomiast swoja prace wykonuje w sposób konkretny, wie, jakie jest jej zadanie, co ma zrobić i tym się przejmuje.

Dawno temu skończyła liceum. A poza pracą interesuje się sportem. A także lubi jeździć na rowerze, pływać, biegać, a do tego na pewno ze swoimi dziećmi biega po boisku i gra w pitke nożna.

Bywa także panią woźny w sqdzie. Wtedy czuje się bardzo ważna w swojej roli i uważa, że ma bardzo odpowiedzialne zajęcie. Nie tylko tatwo nawiqzuje kontakt, ale nawet skazanych czasami pocieszy.

Podsumowujac: pani woźnej przypisane zostały cechy typowo kobiece, w większości pojawiające się już w przypadku innych analizowanych zawodów, takie jak ciepło, wrażliwość na potrzeby innych, opiekuńczość, a także gotowość do poświęcenia dla innych. Natomiast pani woźny, podobnie jak w przypadku krawcowej/krawca przypisane zostały raczej cechy kontrastujące z tymi przypisywanymi pani woźnej, jednak nie będące treścią stereotypu męskości, w używanym tutaj znaczeniu.

Różnice w statusie między opisywanymi osobami widoczne są przede wszystkim w przypisywanym im wykształceniu (pani woźny ma wykształcenie średnie, podczas gdy pani woźna jedynie podstawowe), a także w miejscu pracy, przy założeniu, że praca ze starszą młodzieżą cieszy się większym szacunkiem społecznym, niż praca w szkole podstawowej. Warto również zauważyć, że jedynie w przypadku osoby posługującej się męską formą nazwy zawodu pojawiło się skojarzenie $\mathrm{z}$ bardziej prestiżowym zawodem woźnego sądowego. Tezę, że w tym przypadku nazwa w rodzaju męskim jest bardziej prestiżowa, potwierdzają również wypowiedzi badanych osób: użycie akurat sformułowania [woźny] podnosi trochę prestiż tego zawodu, a także woźny-lepiej to brzmi. 


\section{Monter/monterka}

Pani monterka ma krótkie wtosy i jest średniego wzrostu, ubrana w koszule flanelowa, ogrodniczki z duża ilościq kieszeni, z pasem z narzędziami, do tego torba z innymi narzędziami. Jej życie zawodowe bywa różne - możliwe, że montuje coś drobnego, na przykład, jeśli jest pralka, to pani monterka będzie na pewno montowała jakiś programator, kabelki będzie lutowata. Jednak prawdopodobne jest też, że kiedyś pracowała w jakimś tam magazynie dużej fabryki i ponieważ ta fabryka padta, ona nie miała pracy, dlatego zatrudnita się $w$ spótdzielni mieszkaniowej i jest takq trochę 'złota raczkq'. Jednak istnieje też trzecia możliwość - pani monterka pracuje przy taśmie w zakladzie pracy, a wtedy jest to taki zawód, że faceci nie chca tego wykonywać.

Jej podejście do pracy jest również ambiwalentne. Bywa, że nie jest zbyt solidna i chociaż sie stara to nie przywiqzuje się do tej pracy i nie czuje się $w$ tej roli. Wtedy zrobi swoja prace, wykona i za chwile pójdzie do domu i już ja to nie interesuje, tylko sprawy domowe $i$ jest pochtonięta sprzataniem, gotowaniem. Ale możliwe jest też zupełnie inne wyjście - wtedy jest osoba, która znalazła sposób na życie, można o niej powiedzieć, że ma $5 \%$ powołania $w$ przeciwieństwie do montera, który ma minus 15.

Charakter pani monterki wydaje się również trudny do odszyfrowania - z jednej strony to jakiś babochtop i typ męski, z drugiej bardziej kobieca i subtelna. Bywa bardzo rozmowna, ale bywa również zamknięta $w$ sobie. Może być zdecydowana $i$ nie wtapiajaca się $w$ thum, ale może też ciagle zmieniać decyzje. Czasem umyst ścisły, a czasem, gdy mówi o jakimś mieście, to dla niej ważniejsza atmosfera niż te zabytki.

Niektórzy mówią, że jest jakaś dziwaczna, troszkę zwariowana, a nawet wygłupialska. No i że pani monterka, to może coś zmontować najwyżej.

Pani monter pracuje wśród mężczyzn, montuje telewizory i odpowiedzialne rzeczy bardzo, jak na przykład bęben w pralce. Być może do pracy jako monter trafiła, bo zawsze była takim typem chtopa, a ponieważ przez pewien czas pracowała $w$ zakładzie ogrodniczym na ciagniku i wtedy często naprawiala ten ciagnik, a do tego nigdy jej specjalnie kwiaty nie interesowaty i jej brat skończyt szkołę samochodowa, założyt własny zakład, to ona sobie pomyślała, że może więcej zarobi i więcej na tym zyska, gdy będzie tam robić, pójdzie do niego do tego zaktadu i będzie robić w jego zaktadzie. Ale możliwe także, że ktoś jej tę pracę zaproponowat i nie miata wyboru, bo ma $w$ domu trójkę dzieci i nie ma męża. Choć być może jest zadowolona i taka praca sprawia jej frajdę.

Czasami chciałaby się wtopić $w$ jakaśs takq ekipe, w której pracuje, a także stucha czyichś poleceń $i$ brakuje jej osobistego zaangażowania, a innym razem jest osoba wiodqca $i$ prowadzi jakqś grupę. Jest kompetentna i zna się na swoim fachu, co więcej, jest lepiej przygotowana niż pani monterka. Poza tym widzi w swoim życiu coś więcej niż tylko dom, sprzqtanie i gotowanie.

Pani monter jest konkretna, zdecydowana, a także otwarta i jowialna, choć bywa także małomówna, nieciekawa i zamknięta. Jest również bardziej zrównoważona i zdystansowana niż pani monter, i też mniej rozmowna niż ona. Jest męskim typem, można nawet powiedzieć, że babochlopem. Niektórzy przypuszczają, że to baba w spodniach, uznajaca się za faceta, która na każdym kroku chce udowodnić, że ona potrafi to, co mężczyźni.

Podsumowując: zarówno pani monter jak i pani monterka posiadają wiele cech męskich. Jednak wydaje się, że osoba posługująca się żeńską nazwą zawodu posiada więcej cech kobiecych - takich jak na przykład rozmowność, trudność w podejmowaniu decyzji czy delikatność. Budzi ona również w badanych przeze mnie osobach więcej sympatii.

Wypowiedzi respondentów nie wskazują na dostrzeganie przez nich jakichś wyraźnych różnic w statusie między osobami posługującymi się nazwami w rodzaju męskim lub żeńskim. Jedynym elementem mającym związek z prestiżem jest uznanie, że pani monter jest osobą bardziej kompetentną i lepiej przygotowaną do zawodu. Również w wyrażanych wprost stwierdzeniach tylko raz pojawia się różnicowanie między obiema formami: monterka nie brzmi dobrze.

\section{Zegarmistrzyni/zegarmistrz}

Pani zegarmistrzyni prowadzi taki zakład, w którym naprawia takie stare zegary, na przykład stojace, albo z kukułkq. Wtedy ma taki bardzo ładny zakład, gdzie wisi petno zegarów z kukułkami i bardzo przyjemnie wejść do niego, szczególnie starszym ludziom, którzy lubiq sobie pogadać $z$ panią zegarmistrzynią, bo ona zna historie wielu tych zegarów, potrafi bardzo tadnie o nich 
opowiadać. Chociaż możliwe także, że jest zegarmistrzyniq z nazwy, a nie z tego, co robi, co oznacza, że bierze i ten zegarek daje komuś innemu do zrobienia.

Jest osobą ciepła, cierpliwa i precyzyjna, a być może nawet pedantka. W pracy wszystko robi doktadnie $i w$ życiu tak też postepuje. Jest drobnq kobietkq, tradycyjnq, bardzo wyciszona $i$ spokojna. W porównaniu z panią zegarmistrz bardziej uwypukla swoje żeńskie cechy, a także więcej mówi z klientami i ma odrobinq takiej finezji i takie podejście trochę zawadiackie. Ogólnie jest bardzo sympatyczna, a także bywa bardzo pewna swoich umiejętności.

Pani zegarmistrz zapewne odziedziczyla firme po swoim dziadku i to spowodowato, że pisze zegarmistrz. Jednak jest także możliwe, że jak była młoda, na poczatku chciała być jubilerem, tak jak jej wujek, nawet skończyła jakaśs szkołe tam jubilerska przyzakładowa. Ale potem to jubilerstwo padto $i$ w zwiqzku z tym ona poszła na jakiegoś tam zegarmistrza $w$ termin, żeby się troszeczke poduczyła $i$ w ten sposób została zegarmistrzem.

Jest fachowcem $w$ swojej dziedzinie $i$ wykonuje poprawnie wszystkie naprawy $w$ zegarku, a każdy klient może o niej powiedzieć: „Mój spis zepsutych zegarków chce się z niq zobaczyć”. Innymi słowy, jest osoba, do której sie przychodzi i daje się zegarek i się odbiera ten zegarek naprawiony. Chociaż możliwe także, że pani zegarmistrz nie tyle, że naprawia te zegarki, co ma taki mały sklepik z tymi zegarkami, bardzo skromny.

Jako człowiek jest przede wszystkim cierpliwa, precyzyjna $i$ wyważona $w$ ruchach. A także stara się być dość sumienna i bardzo drobiazgowa. W pracy jest pedantka, natomiast $w$ domu niekoniecznie. W porównaniu z panią zegarmistrzynią jest chtodniejsza i bardziej pewna siebie, a także lepiej wykonujaca swoja pracę. Miewa także drugie oblicze - wtedy jest dowcipna, a może nawet taka trochęflirciara. Mówiąc inaczej: kobieta z jajem.

Podsumowujac, w charakterystyce zarówno pani zegarmistrz, jak i pani zegarmistrzyni przeważają cechy potocznie kojarzone z tym zawodem - takie jak precyzja, spokój czy opanowanie. Potwierdza to opinia jednej z badanych osób: jakie by nie byty to sq takie same. Jednak w przypadku żeńskiej formy nazwy zawodu cechy żeńskie wydają się nieco bardziej uwypuklone, co widać zarówno $\mathrm{w}$ deklaracjach wprost, jak i w pojawieniu się cech typowo żeńskich - na przykład ciepło czy rozmowność.

Różnice dotyczące prestiżu są także w tym przypadku widoczne głównie w ocenie fachowości obu osób - podobnie jak w pozostałych analizowanych zawodach, osoba posługująca się męską nazwą zawodu uznawana jest za posiadającą wyższą kompetencję zawodową. Respondenci deklarowali także zdziwienie i nieufność wobec formy żeńskiej: dziwne to dla mnie, a także zupetnie bym nie wiedziała, czym się zajmuje ta pani zegarmistrzyni.

\section{Sędzina/sędzia}

Pani sędzina bywa po prostu żonq sędziego. Wtedy jest zawodowo trochę uśpiona, bardziej opierajaca się na prestiżu zawodowym męża. Oznacza to również, że jest nastawiona nie na siebie, ale na innych, motywujaca innych do działania, ale nie przykładajaca wagi do swojego rozwoju, czekajaca na jakiś moment w życiu, który pozwoli bardziej jej zaangażować się zawodowo.

Jednak przeważnie jest to kobieta wykonująca zawód sędziego, na przykład jest sędzina $w$ sqdzie dla nieletnich. Zawodowo ma dwa oblicza. Bywa bardzo niesympatyczna, bardzo sucha $w$ wykonywaniu swojej pracy, wtedy wszystko przebiega szybko, bez wnikania w to, kto ma racje, oczywiście wszystko zgodnie z literq prawa, ale jednak do tego sqdu nie chce się trafić. Ale bywa też dobrym sędziq, dobra sędzina - na sali rozpraw wnikliwie wstuchuje się $w$ wypowiedzi wszystkich osób, a wszystkie decyzje podejmuje rozważnie starając się uwzględnić jakby wszystkie za i przeciw. Stara się, ażeby jej decyzja byta sprawiedliwa.

Pani sędzina ma duża rodzinę. Być może nawet ma już wnuki. Bywa, że tak jak jest sędzina $w$ pracy, tak jest też sędzinq $w$ domu. Mówi dobitnym, stanowczym, zdecydowanym głosem i jest bardzo surowa, a czasem także chtodna $i$ wyniosta. Jednak może być też życzliwie nastawiona do świata, a także łatwo nawiazywać kontakty i starać się wystuchać innych. Jest też bardziej otwarta na ludzi i cieplejsza $w$ stosunku do [nich] niż pani sędzia, ale obie kobiety sq bardzo rzeczowe $i$ zarówno jedna jak $i$ druga bardzo profesjonalne. Pani sędzina to także osoba elegancka, kompetentna i rzeczowa.

Pani sędzia bywa sędzią $w$ sqdzie pierwszej instancji i jest zdeterminowana na awans i dlatego stara się wykonywać swoja prace jak najlepiej, nawet jest perfekcjonistka. Zdarza się też, że 
pracuje w sqdownictwie już 15 lat. Wtedy zaczynaja ja już nużyć, drażnić te problemy, a ona sama jest zdecydowanie sfrustrowana i zastanawia się, czy tego nie porzucić.

W pracy zawodowej mniej widzi czlowieka, a więcej przepisy, zasady, prawo w konkretnych punktach, można powiedzieć: taki chodzacy paragraf. Bywa ostra, sucha i wyrachowana. Jednak jest również możliwe, że pani sędzia to bardzo konkretna, fajna dziewczyna, a nawet trochę trzpiotowata. Zdecydowanie wie, co $w$ życiu chce osiagnać $i$ to się dla niej liczy. Ale jest także sympatyczna, sprawiedliwa i sumienna. A do tego można też powiedzieć, że jest ciepła, chociaż więcej ciepła rozsyła wokót siebie w domu.

Podsumowujac: zarówno pani sędzia jak i pani sędzina mają różne oblicza - bywają one zbliżone do stereotypowych kobiet - są ciepłe, a także wrażliwe na uczucia i potrzeby innych. Jednak bywają też bardzo podobne do stereotypowych mężczyzn - racjonalne, opanowane i niezbyt wrażliwe. Na uwagę zasługują dwa zjawiska - po pierwsze tylko przy opisie kobiety posługującej się nazwą sędzina pojawia się szerszy i bardziej szczegółowy opis dotyczący jest sytuacji domowo-rodzinnej, a więc sfery potocznie kojarzonej z kobiecością. Po drugie - w opisie pani sędzi respondenci mówią o dążeniu do awansu, co z kolei związane jest $\mathrm{z}$ cechami typowo męskimi takimi jak ambicja czy skłonność do rywalizacji. Można zatem uznać, że w przypadku sędziny/sędziego rodzaj gramatyczny nazwy zawodu jest związany z przenoszeniem stereotypów płciowych, jednak związek ten jest dość słaby.

Zróżnicowanie statusu obu nazw jest dość słabo widoczne w wypowiedziach respondentów, poza przypadkami, w których osoby badane uznały, że sędzina jest żoną sędziego. Natomiast w wypowiedziach wprost dość wyraźnie widoczny jest wyższy status nazwy męskiej: [sędzia] to jest poprawna wersja, [kobiety wykonujace ten zawód] chca, żeby się do nich tak zwracać, a także [sędzia] wzbudza większe zaufanie.

\section{Podsumowanie}

Zaprezentowana powyżej analiza ilościowa nie potwierdziła żadnego ze sformułowanych przed rozpoczęciem badań przypuszczeń. Jednak przyjąć można, że dlatego uzyskane wyniki wydają się tym bardziej interesujące i zachęcają do kolejnych badań poświęconych temu zagadnieniu. Jakościowy charakter poprowadzonych badań, który niestety związany jest z doborem małej i niereprezentatywnej próby, sprawia, że przedstawione tu dane ilościowe nie mogą być podstawą do formułowania uogólnień dotyczących całej populacji. Jednak prowadzone badania miały na celu przede wszystkim ogólne i wstępne naszkicowanie zjawisk związanych z przenoszeniem statusu przez rodzaj gramatyczny nazwy zawodu, którą posługuje się kobieta. Sformułowanie twierdzeń mających charakter wyjaśniający, a także dokładny opis tego zjawiska $\mathrm{w}$ całej populacji, wymagałby przeprowadzenia badań ilościowych. Przyjąć jednak można, że uzyskane w tych badaniach wyniki, często różne od intuicyjnych przypuszczeń, zachęcają do dalszej eksploracji tego tematu.

Natomiast sformułowany w analizie jakościowej i przytoczony powyżej dość szczegółowy opis cech przypisywanych osobom posługującym się poszczególnymi formami nazw zawodów, ukazuje przede wszystkim istnienie zróżnicowania między postrzeganiem kobiet, które posługą się nazwą żeńską zawodu, a tych, które używają nazw męskich. Tym samym można uznać, że rodzaj gramatyczny nazwy zawodu wpływa na to, jak postrzegana jest osoba, która się nim posługuje.

Dwa zjawiska związane z tym wpływem pojawiły się w przypadku wszystkich omawianych $\mathrm{w}$ tej pracy zawodów. Po pierwsze, zawsze osobie posługującej się żeńską formą nazwy przypisywano więcej cech żeńskich. Zależność ta nie pojawia się jednak w przypadku nazw męskich, które nie zawsze są silnie kojarzone ze stereotypowo męskimi cechami. Można więc stwierdzić, że dla osób objętych prezentowanymi tutaj badaniami żeński rodzaj gramatyczny nazwy zawodu jest dość silnym nośnikiem skojarzeń związanych z cechami przypisywanymi stereotypowym kobietom.

Drugim interesującym zjawiskiem jest, pojawiające się również w przypadku wszystkich zbadanych zawodów, przypisywanie osobom używającym nazwy męskiej większej fachowości w swoim zawodzie. Związek ten zachodzi nawet w przypadku zawodu położnej/położnego, kiedy 
to forma męska budziła bardzo silne negatywne skojarzenia, a mimo to właśnie osobie nią się posługującej, przypisano większą wiedzę dotyczącą wykonywanego zawodu. Zatem można przyjąć, że rodzaj męski w przypadku nazwy zawodu był przez respondentów silnie kojarzony $\mathrm{z}$ wysoką kompetencją osoby, która się nim posługuje.

Wydaje się również, że różnice między postrzeganiem kobiet posługujących się nazwą męską i nazwą żeńską zawodu $\mathrm{w}$ przypadku opisanych powyżej zawodów można podzielić na kilka kategorii:

> Zarówno nazwa żeńska, jak i nazwa męska jest silnym nośnikiem cech stereotypowych dla płci. Towarzyszy temu zróżnicowanie statusu obu nazw, przy czym nazwa w rodzaju męskim kojarzona jest jednoznacznie $z$ wyższym prestiżem. Spośród badanych tutaj zawodów do tej kategorii zaliczyć można nauczycielkę/nauczyciela, wychowawczynię/wychowawcę, starościnę/staroste (powiatu), fryzjerkęfryzjera, a także księgowa/księgowego, choć w tym przypadku wyżej opisane zróżnicowanie jest nieco mniej wyraźne.

$>$ Nazwy żeńskie silnie przenoszą stereotypowo rozumianą kobiecość, natomiast z nazwami męskimi kojarzone są raczej zaprzeczenia cech stereotypowo kobiecych, niż cechy stanowiące treść stereotypu męskości. Status osób posługujących się obiema nazwami jest dość wyrównany, choć kobiety używające męskiej formy nazwy uznawane są za bardziej fachowe i kompetentne. Tego typu zróżnicowanie pojawia się wśród opisywanych tutaj zawodów w przypadku dozorczyni/dozorcy, woźnej/woźnego, a także krawcowej/krawca i położnej/położnego. W przypadku dwóch ostatnich zawodów wyraźny jest też negatywny ładunek emocjonalny łączony $\mathrm{z}$ męską formą nazwy. Jest on szczególnie wyraźny w przypadku położnej/położnego. ${ }^{11}$

$>$ Charakterystyka obu osób jest zdominowana przez cechy potocznie kojarzone z danym zawodem. Osobom posługującym się nazwą żeńską przypisywanych jest nieco więcej cech stereotypowo kobiecych, zaś używającym formy męskiej - większa fachowość. Spośród badanych przeze mnie zawodów zaliczyć tu można zegarmistrzynię/zegarmistrza i monterkę/montera.

Widać zatem, że różnice między postrzeganiem osób posługujących się żeńską nazwą zawodu, a tych, które używają nazw męskich, przybierają przynajmniej kilka form. Pytania co decyduje o tym, do jakiej z powyżej opisanych kategorii zalicza się dana nazwa zawodu, a także, czy przedstawiona powyżej lista jest wyczerpująca, należy uznać za otwarte. Znalezienie odpowiedzi na nie wymagałoby przeprowadzenia znaczeni bardziej rozbudowanych i szczególnych badań.

„[Słowo] nie jest mapą rzeczywistości” (Griffin 2003) pisał Pearce. Przytoczone powyżej wyniki zapewne niewiele mówią o kobietach, które używają w stosunku do siebie nazwy zawodu w rodzaju męskim lub w rodzaju żeńskim. Są jak stereotypy, które są jedynie pewnymi uogólnieniami, niewrażliwymi na indywidualne cechy poszczególnych osób. Jednak zarówno powyższe opisy jak i wyniki analizy ilościowej pokazuja, jak kobiety mogą być postrzegane, jakie skojarzenia uruchamia i jaki wizerunek tworzy nazwa zawodu w rodzaju żeńskim, a jakie w rodzaju męskim, a także, jak ta pozornie niewielka różnica gramatyczna przekłada się na zróżnicowanie w statusie. Jeśli wierzyć Josephowi Bergerowi i innym interakcjonistom symbolicznym, są to informacje, które istotnie wpływają na interakcje w świecie społecznym.

\footnotetext{
${ }^{11}$ Być może można to tłumaczyć odwrotnym, niż w przypadku wszystkich pozostałych badanych zawodów, kierunkiem derywacji nazwy. W tym przypadku bowiem to forma żeńska stanowi podstawę do utworzenia nazwy męskiej.
} 
Victoria Kamasa: Fryzjer czy fryzjerka? Rodzaj gramatyczny nazwy zawodu jako nośnik statusu społecznego

\section{Bibliografia}

Aronson, E. 2004. Człowiek istota społeczna. Warszawa: PWN.

Babbie, E. 2003. Badania społeczne w praktyce. Warszawa: Wydawnictwo Naukowe PWN.

Berger, J., Fisek, M. H., Norman, R.Z., Zelditch M. 1977. Status characteristics and social interaction. An ExpextationStates Approach. Nowy Jork: Elsevier.

Brannon, L. 2002. Psychologia rodzaju. Gdańsk: Gdańskie Wydawnictwo Psychologiczne.

Budrowska, K. 2000. Kobieta i stereotypy oraz obrazy kobiet w prozie polskiej po roku 1989. Białystok: Trans Humana.

Griffin, E. 2003. Podstawy komunikacji społecznej. Gdańsk: Gdańskie Wydawnictwo Psychologiczne.

Jadacka, H. 2005. Kultura języka polskiego. Fleksja, słowotwórstwo, składnia. Warszawa: Wydawnictwo Naukowe PWN.

Kvale, S. 2004. InterViews. Wprowadzenie do jakościowego wywiadu badawczego. Białystok: TransHumana.

Nachmias, D., Frankfurt-Nachmias Ch. 2001. Metody badawcze w naukach spolecznych. Poznań: Wydawnictwo Zysk i S-ka.

Nagórko, A. 1998. Zarys gramatyki polskiej (ze stowotwórstwem). Warszawa: Wydawnictwo naukowe PWN.

Satkiewicz, H., Buttler, D., Kurkowska, H. 1973. Kultura języka polskiego. Warszawa: PWN.

Szacki, J. 2002. Historia myśli społecznej. Warszawa: Wydawnictwo Naukowe PWN.

Tuner, J. H. 2004. Struktura teorii socjologicznej. Warszawa: Wydawnictwo Naukowe PWN.

Weber, M. 1985. "Obiektywność" poznania w naukach społecznych, w: Rainko, S. (red), Problemy socjologii wiedzy. Warszawa: PWN. 